\title{
\#USGS
}

Prepared in cooperation with New York State Department of Environmental Conservation

\section{Hydrogeology of the Susquehanna River Valley-Fill Aquifer System and Adjacent Areas in Eastern Broome and Southeastern Chenango Counties, New York}

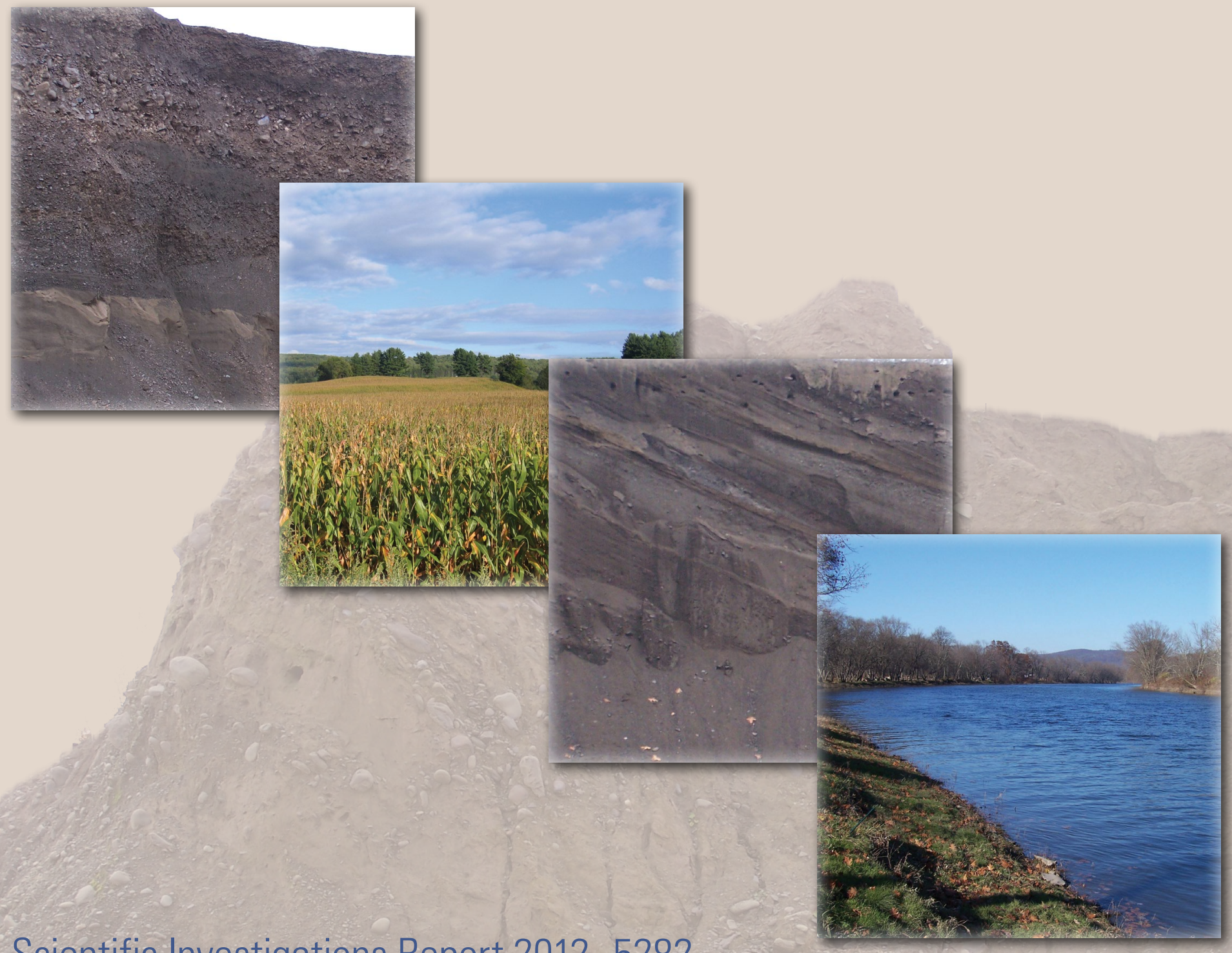

Scientific Investigations Report 2012-5282 


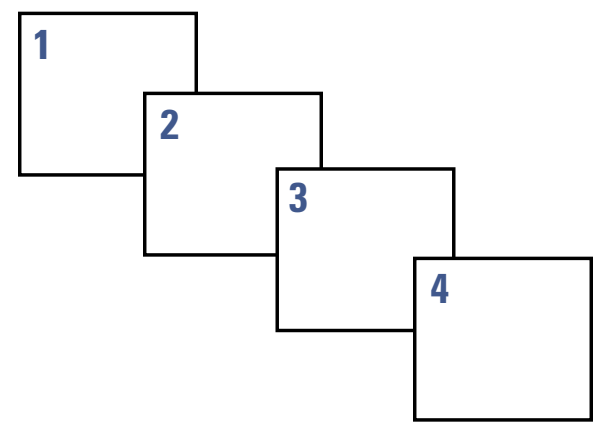

Cover. Background. Ice-contact deposit exposed in a gravel pit near South Windsor, New York 1. Outwash deposit exposed in a gravel pit near Center Village, New York (N.Y.)

2. Near Bettsburg, N.Y., looking north

3. Kame delta deposit south of bedrock hill (umlaufberg) at East Windsor, N.Y.

4. Susquehanna River, looking north, near South Windsor, N.Y. 


\section{Hydrogeology of the Susquehanna River Valley-Fill Aquifer System and Adjacent Areas in Eastern Broome and Southeastern Chenango Counties, New York}

By Paul M. Heisig

Prepared in cooperation with New York State Department of Environmental Conservation

Scientific Investigations Report 2012-5282 


\section{U.S. Department of the Interior \\ KEN SALAZAR, Secretary}

\section{U.S. Geological Survey \\ Suzette M. Kimball, Acting Director}

U.S. Geological Survey, Reston, Virginia: 2013

For more information on the USGS - the Federal source for science about the Earth, its natural and living resources, natural hazards, and the environment-visit http://www.usgs.gov or call 1-888-ASK-USGS

For an overview of USGS information products, including maps, imagery, and publications, visit http://www.usgs.gov/pubprod

To order this and other USGS information products, visit http://store.usgs.gov

Suggested citation:

Heisig, P.M., 2013, Hydrogeology of the Susquehanna River valley-fill aquifer system and adjacent areas in eastern Broome and southeastern Chenango Counties, New York: U.S. Geological Survey Scientific Investigations Report 2012-5282, 19 p., at http://pubs.usgs.gov/sir/2012/5282.

Any use of trade, firm, or product names is for descriptive purposes only and does not imply endorsement by the U.S. Government.

Although this information product, for the most part, is in the public domain, it also may contain copyrighted materials as noted in the text. Permission to reproduce copyrighted items must be secured from the copyright owner. 


\section{Acknowledgments}

The author expresses sincere thanks to Duane Braun, Bloomsburg Unversity (retired) for his helpful review comments and insight. He graciously provided his interpreted ice-margin positions, which are the basis of ice positions presented here. Special thanks also are extended to Allan Randall, USGS retired, for his comments, informative discussions, patience, and tireless effort.

Todd Miller, USGS, is also acknowledged for his many helpful review comments and suggestions. 
THIS PAGE INTENTIONALLY LEFT BLANK 


\section{Contents}

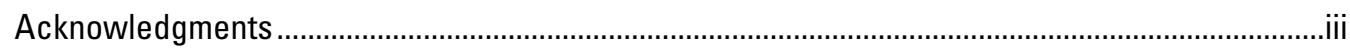

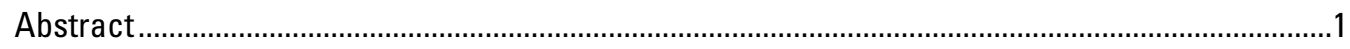

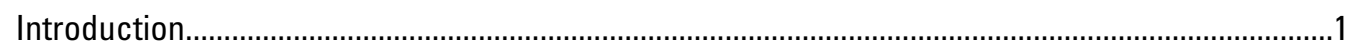

Purpose and Scope ......................................................................................................

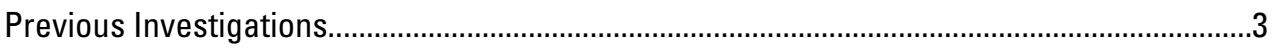

Glacial Geology and Geomorphology ........................................................................

Outwash and Alluvial Stratigraphy in the Susquehanna River Valley ...............................3

Stratified-Drift Aquifer Extent and Hydrogeology ..............................................................

Data Sources and Methods ................................................................................................

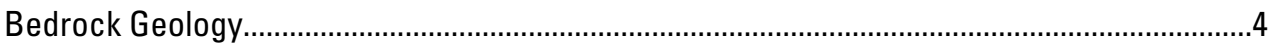

Spatial Distribution of Glacial and Holocene Deposits ...................................................................

Stratified-Drift Deposits Associated with Stagnation-Zone Retreat of Active Ice in the

Susquehanna River Valley .......................................................................................5

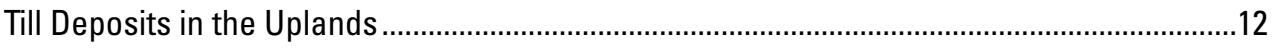

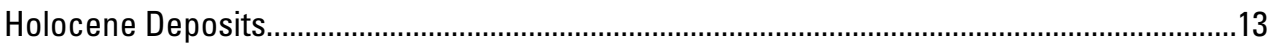

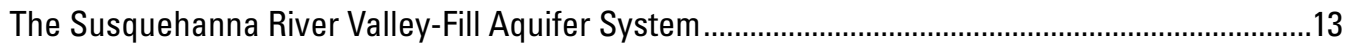

Areas of Favorable Water-Resource Potential....................................................................14

Sources of Groundwater and Groundwater Flow ................................................................14

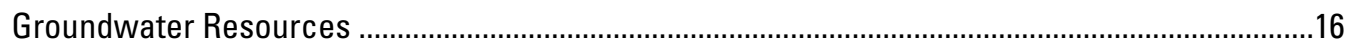

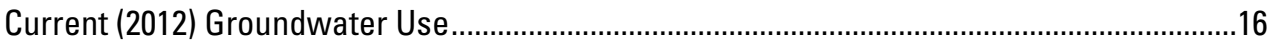

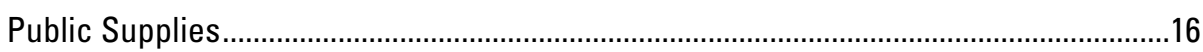

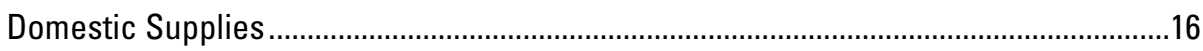

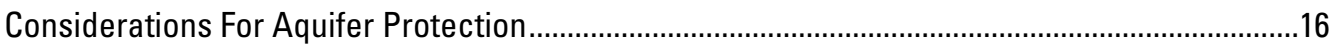

Upland Watersheds that Contribute Water to the Susquehanna Valley-Fill Aquifer ..............17

Upland Areas of Thin Till over Bedrock...........................................................................

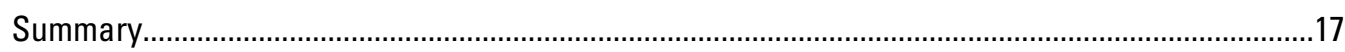

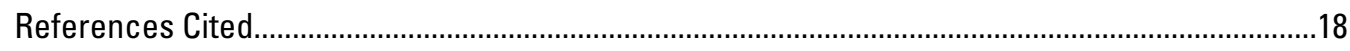

Appendix 1. Well data for Susquehanna River valley and adjacent uplands, eastern Broome and southeastern Chenango Counties, New York. ……………………………………...21

\section{Plate}

Plate 1. Hydrogeology of the Susquehanna valley-fill aquifer system and adjacent areas in eastern Broome and southeastern Chenango Counties, New York LINK

\section{Figures}

1. Map showing location of the study area and extent of stratified drift along the Susquehanna River valley in eastern Broome and southeastern Chenango Counties, New York

2. Geohydrologic section $A-A^{\prime}$ east of Bainbridge, Chenango County, New York................7

3. Geohydrologic section B-B' east of Afton, Chenango County, New York ........................8

4. Geohydrologic section $C-C^{\prime}$ south of Harpursville of Broome County, New York.............9 
5. Geohydrologic section D-D' at Ouaquaga, Broome County, New York ...........................

6. Geohydrologic section E-E' at Windsor, Broome County, New York..............................10

7. Schematic diagram showing the longitudinal valley geologic section morphosequences that represent long (left) and short (right) pauses in the retreat of the ice margin

8. Map showing distribution of aquifer types and settings within the Susquehanna River valley-fill aquifer system, eastern Broome and southeastern Chenango Counties, New York

9. Schematic diagram showing longitudinal valley geologic section aquifer types and occurrences in relation to the morphosequence distribution of stratified drift.

10. Conceptual block diagram of groundwater flow in the Susquehanna valley-fill aquifer system.

\section{Tables}

1. Statistics of well yields for wells in upland and valley areas, eastern Broome and southeastern Chenango Counties, New York. Well yields reported by drillers, New York State Well Permit Program (2000-10) 


\section{Conversion Factors, Datum, and Abbreviations}

Inch/Pound to SI

\begin{tabular}{|c|c|c|}
\hline Multiply & By & To obtain \\
\hline \multicolumn{3}{|c|}{ Length } \\
\hline foot $(\mathrm{ft})$ & 0.3048 & meter $(\mathrm{m})$ \\
\hline mile (mi) & 1.609 & kilometer (km) \\
\hline \multicolumn{3}{|c|}{ Flow rate } \\
\hline foot per minute (ft/min) & 0.3048 & meter per minute $(\mathrm{m} / \mathrm{min})$ \\
\hline foot per day (ft/d) & 0.3048 & meter per day (m/d) \\
\hline cubic foot per second $\left(\mathrm{ft}^{3} / \mathrm{s}\right)$ & 0.02832 & cubic meter per second $\left(\mathrm{m}^{3} / \mathrm{s}\right)$ \\
\hline gallon per minute (gal/min) & 0.06309 & liter per second $(\mathrm{L} / \mathrm{s})$ \\
\hline \multicolumn{3}{|c|}{ Hydraulic conductivity } \\
\hline foot per day (ft/d) & 0.3048 & meter per day $(\mathrm{m} / \mathrm{d})$ \\
\hline \multicolumn{3}{|c|}{ Hydraulic gradient } \\
\hline foot per mile ( $\mathrm{ft} / \mathrm{mi})$ & 0.1894 & meter per kilometer $(\mathrm{m} / \mathrm{km})$ \\
\hline
\end{tabular}

North American Vertical Datum of 1988 (NAVD 88).

Horizontal coordinate information is referenced to North American Datum of 1983 (NAD 83).

Altitude, as used in this report, refers to distance above the vertical datum.

\section{Abbreviations}

GWSI Groundwater Site Inventory

LiDAR Light Detection and Ranging

NWIS National Water Information System

NYSDEC New York State Department of Environmental Conservation

USGS U.S. Geological Survey 
THIS PAGE INTENTIONALLY LEFT BLANK 


\section{Hydrogeology of the Susquehanna River Valley-Fill Aquifer System and Adjacent Areas in Eastern Broome and Southeastern Chenango Counties, New York}

by Paul M. Heisig

\section{Abstract}

The hydrogeology of the valley-fill aquifer system along a 32-mile reach of the Susquehanna River valley and adjacent areas was evaluated in eastern Broome and southeastern Chenango Counties, New York. The surficial geology, inferred ice-marginal positions, and distribution of stratified-drift aquifers were mapped from existing data. Ice-marginal positions, which represent pauses in the retreat of glacial ice from the region, favored the accumulation of coarse-grained deposits whereas more steady or rapid ice retreat between these positions favored deposition of fine-grained lacustrine deposits with limited coarse-grained deposits at depth. Unconfined aquifers with thick saturated coarse-grained deposits are the most favorable settings for water-resource development, and three several-mile-long sections of valley were identified (mostly in Broome County) as potentially favorable: (1) the southernmost valley section, which extends from the New York-Pennsylvania border to about 1 mile north of South Windsor, (2) the valley section that rounds the west side of the umlaufberg (an isolated bedrock hill within a valley) north of Windsor, and (3) the east-west valley section at the Broome County-Chenango County border from Nineveh to East of Bettsburg (including the lower reach of the Cornell Brook valley). Fine-grained lacustrine deposits form extensive confining units between the unconfined areas, and the water-resource potential of confined aquifers is largely untested.

Recharge, or replenishment, of these aquifers is dependent not only on infiltration of precipitation directly on unconfined aquifers, but perhaps more so from precipitation that falls in adjacent upland areas. Surface runoff and shallow groundwater from the valley walls flow downslope and recharge valley aquifers. Tributary streams that drain upland areas lose flow as they enter main valleys on permeable alluvial fans. This infiltrating water also recharges valley aquifers.

Current (2012) use of water resources in the area is primarily through domestic wells, most of which are completed in fractured bedrock in upland areas. A few villages in the Susquehanna River valley have supply wells that draw water from beneath alluvial fans and near the Susquehanna River, which is a large potential source of water from induced infiltration.

\section{Introduction}

This study is a continuation of a series of hydrogeologic appraisals that have been conducted since 1980 in cooperation with the New York State Department of Environmental Conservation (NYSDEC) through the Aquifer Mapping Program. These reports provide a foundation for wellhead protection programs, water-resource management and planning decisions, and groundwater remediation in upstate New York (N.Y.).

In 2009, the U.S. Geological Survey (USGS), in cooperation with the NYSDEC, began an appraisal of the aquifer system in a 32-mile (mi) reach of the Susquehanna River valley and adjacent areas in eastern Broome and southeastern Chenango Counties, New York (fig. 1). The area of investigation has substantial natural-gas resource potential in the underlying Marcellus Shale and Utica Shale, and therefore could be subject to future gas-drilling activities. Therefore, aquifer mapping and an understanding of sources of water that replenish the aquifer, along with current water-resource use in the valleys and upland areas, was warranted for management and protection of this water resource.

\section{Purpose and Scope}

This report summarizes the hydrogeology of the valleyfill aquifer system in the Susquehanna River valley and large tributary valleys for the 32-mi section within eastern Broome and southeastern Chenango Counties, extending from the New York-Pennsylvania State line north to Sidney, N.Y. (fig. 1). An 


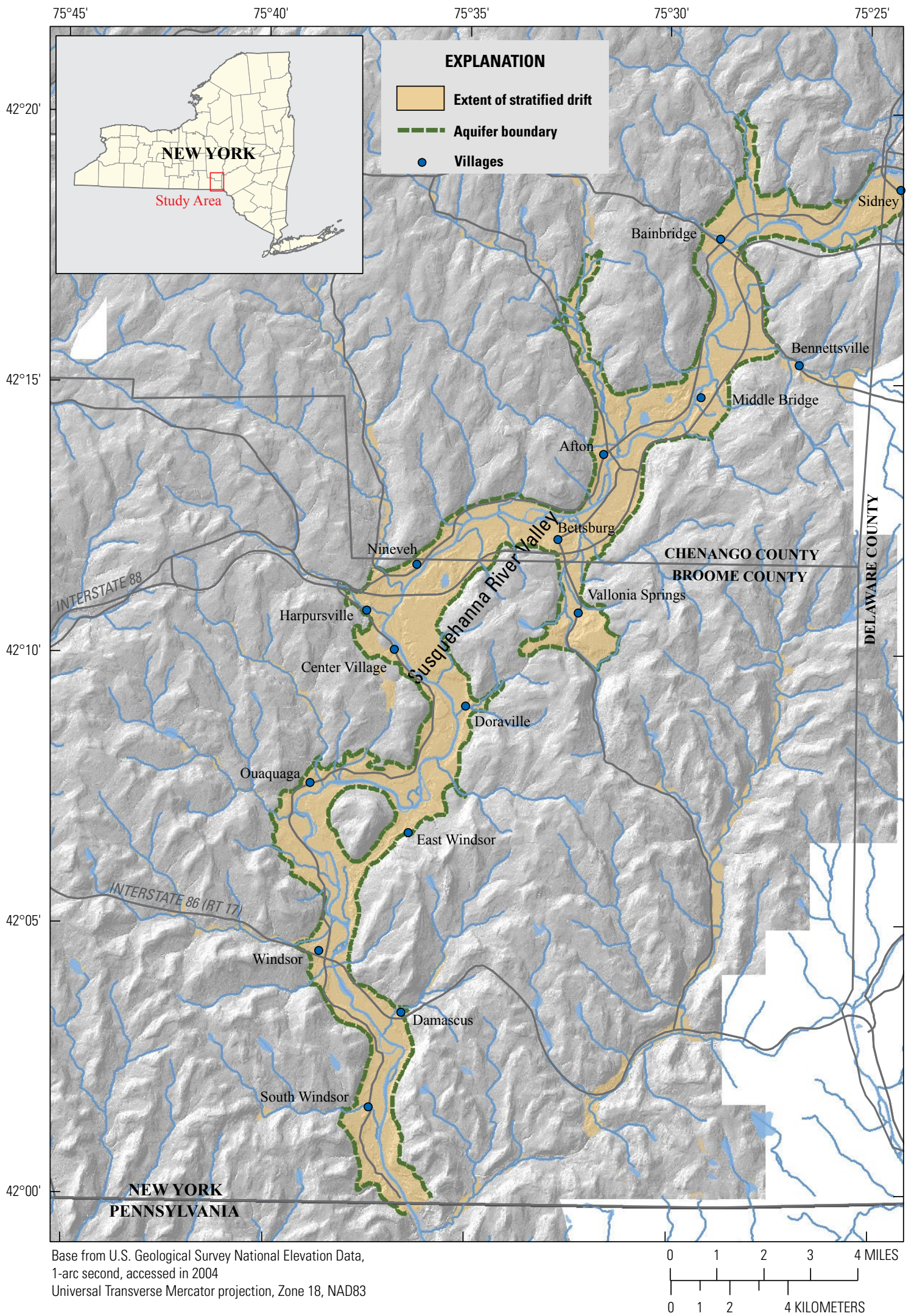

Figure 1. Location of the study area and extent of stratified drift along the Susquehanna River valley in eastern Broome and southeastern Chenango Counties, New York. 
interactive map plate was constructed with several layers of information:

1. extent of the valley-fill aquifer system

2. surficial geology

3. extent of subsurface lacustrine confining units

4. locations of geologic sections and links to accompanying illustrations

5. well and seismic-survey locations

6. high-resolution LiDAR (Light Detection and Ranging) and imagery of land surface

7. topographic contours

Figures depict the study area, geologic sections, favorable water-resource areas within the Susquehanna River valley, and a conceptual diagram of groundwater flow. Accompanying text summarizes bedrock and glacial geology and describes the hydrogeologic framework and a general conceptual model of the groundwater flow system. The hydrogeology of the upland areas are briefly discussed in the context of (1) the fractured bedrock aquifer that serves as a source of water for domestic wells, and (2) as a source of recharge to the stratified-drift aquifer system. Water availability, current water use, and considerations for water-resource protection are described.

A table of well data is included in appendix 1 .

\section{Previous Investigations}

Previous work in the study area and surrounding region is categorized into three main topics: (1) glacial geology and geomorphology in the region, (2) outwash and alluvial stratigraphy in the Susquehanna River valley, and (3) stratified-drift aquifer extent and hydrogeology.

\section{Glacial Geology and Geomorphology}

Cadwell (1972) mapped glacial deposits and outflow channels in the study area and in the adjoining Chenango and Unadilla River Basins and interpreted a series of ice-marginal positions across the entire area. Fleisher (1986b) delineated ice-marginal positions in the Susquehanna River Basin upstream (north of Sidney, N.Y.) of the study area, and Harrison (1966) and Braun (2002, 2006a, 2006b, 2006c) mapped glacial deposits and mapped ice-marginal positions and described the deglaciation drainage histories in the Susquehanna River Basin at the downstream (southern) end of the study area including the Great Bend area of the Susquehanna River in Pennsylvania (Pa.; outside study area and not shown on any figure). Glacial mapping and interpretations of deglacial events in the Delaware River Basin due east of the study area were reported by Kirkland (1973) and Ozvath (1985).
Fleisher (1986a, 1986b, and 1993) has done extensive work in the upper Susquehanna River Basin that has application within the study area. Fleisher (1986b) (1) related topographic control of ice margins to the mode of deglaciation (backwasting or downwasting ice, generally in the presence of proglacial lakes) and therefore, to landforms and stratigraphy, and (2) interpreted a common stratigraphic sequence beneath valley floors. This sequence consists of a gravel cap of as much as $50 \mathrm{feet}$ (ft; outwash) that overlies as much as $200 \mathrm{ft}$ of silt and sand (lacustrine deposits) and below that, a highly variable thickness of coarse gravel. Fleisher (1986a) described and presented examples of ice-stagnation zone features termed 'dead-ice sinks', which are anomalously wide floodplain areas that were the former locations of large detached ice blocks. Fleisher (1993) also presented a modified ice-tongue model in which ice tongues in major valleys extended perhaps 20 kilometers $(\mathrm{km})$ beyond the limit of ice-covered uplands, and discussed the relative importance of upvalley and localupland sediment sources in valley deposits. Glacial landform assemblages were described and related to depositional environments, rates of ice retreat, and topography.

Coates (1966) recognized the asymmetric distribution of till in upland areas of the glaciated Appalachian Plateau. Till thickness, in general, is greatest on the lee (south-southwest facing) side of hills relative to the advance of glacial ice. These areas of thick till, termed "till shadows", typically shift drainage courses southward in east-west oriented valleys and westward in north-south oriented valleys and may blanket stratified materials deposited in previous stream courses.

Till knobs or masses in tributary valleys of the region have been associated with different origins. Till knobs in some north-south oriented "beaded valleys" are interpreted as representing moraines that record pauses in the retreat of glacial ice that were later smoothed by periglacial activity (Braun, 2002, 2006c). Other till features in small valleys were interpreted as glacial or periglacial landforms (King and Coates, 1973). They documented concavo-convex landforms of till in glacially-widened north-south oriented tributary valley bottoms in the southern part of the study area (east of Windsor, N.Y.). These features that have locally shifted stream channels to the opposite side of the valley. Their interpretation was that till in small side valleys had slumped into the valleys following loss of support from glacial ice and with the onset of periglacial conditions.

\section{Outwash and Alluvial Stratigraphy in the Susquehanna River Valley}

Studies of alluvial stratigraphy in the Susquehanna River valley provide a basis for differentiating and mapping Pleistocene stratified-drift deposits and Holocene (less than 10,000 years before present) floodplain and alluvial fan deposits. A detailed study of terrace and floodplain deposits (Scully and Arnold, 1981) within and immediately north of the study area differentiated Holocene (F, T1) terraces from Pleistocene 
$(\mathrm{T} 2, \mathrm{~V})$ terraces based on radiocarbon age - dates and the presence or absence of vertical accretion deposits (fine-grained overbank deposits; see p. 342, Scully and Arnold, 1981). T2 and $\mathrm{V}$ terraces were generally older than 10,000 years and lack vertical accretion deposits. Thieme (2002) also reported on a T2 terrace composed largely of Pleistocene outwash, downstream on the Susquehanna River at Great Bend, Pa.

\section{Stratified-Drift Aquifer Extent and Hydrogeology}

Previous work on the stratified-drift aquifers within the study area includes two regional studies of the New York part of the Susquehanna River Basin, a study of Chenango County stratified-drift aquifers, and a comprehensive study of stratified-drift aquifers in the glaciated northeastern United States. The Susquehanna River Basin studies include estimates of potential well yields from stratified-drift aquifers (Hollyday, 1969), and classification of valley reaches by glacial geology (depositional environment and resulting stratigraphy), aquifer type, and saturated thickness of aquifer material (MacNish and Randall, 1982). Well- and test-boring records for the Susquehanna River Basin in New York were compiled by Randall (1972). McPherson (1993) reported on the hydrogeology of unconsolidated deposits in Chenango County, N.Y., including well data and locations, types of stratified-drift aquifers, potential well yields, and thickness of unconsolidated deposits. Randall (2001) provides a detailed synthesis of the hydrogeologic framework of stratified-drift aquifers in the northeastern United States, formalizing the three depositional facies that parallel the three widespread stratigraphic units described by Fleisher (1986b). The northeast is divided into hydrophysiographic regions and subregions that differ in depositional environments and aquifer geometries. Randall (2001) also presents a comprehensive approach to the appraisal of the hydrogeologic framework of stratified-drift aquifers.

The importance of tributary streamflow infiltration as a source of recharge to stratified-drift aquifers has been documented in the Appalachian Plateau by Crain (1966), Randall (1978), and Williams (1991). Streamflow losses chiefly occur where the streams cross alluvial-fan deposits in the main valleys.

\section{Data Sources and Methods}

Delineation of surficial geology, subsurface deposits, and identification of aquifer boundaries were performed with well data, SSURGO digital soil-survey data (U.S. Department of Agriculture, 2008; http://soildatamart.nrcs.usda.gov), LiDAR imagery, and geologic mapping by previous workers. Sources of well data include previous USGS groundwater studies, especially Randall (1972), and the USGS National Water Information System (NWIS; U.S. Geological Survey, 2001; http://waterdata.usgs.gov/nwis/), well records obtained from the NYSDEC Water Well Drillers Registration Program, and New York State Department of Transportation test boring data (appendix 1). All records collected for this study were entered into the USGS NWIS database (U.S. Geological Survey, 2001) and are accessible at http://waterdata.usgs.gov/nwis/.

Passive seismic, or H/V ambient-noise seismic surveys, were performed at 23 sites to estimate the thickness of sediments over bedrock. The H/V ambient-noise seismic method uses a single broadband three-component ( $\mathrm{x}, \mathrm{y}$, and $\mathrm{z}$ directions) seismometer to record ambient seismic noise. The ratio of the averaged horizontal $(\mathrm{x}, \mathrm{y})$ to vertical $(\mathrm{z})$ frequency spectrum is used to determine the fundamental site resonance frequency, which can be interpreted using regression equations to estimate sediment thickness over bedrock (Lane and others, 2008).

\section{Bedrock Geology}

Bedrock in the study area consists of clastic sedimentary rock of Upper Devonian age (Rickard and Fisher, 1970; Fisher and others, 1970). The bedrock units dip gently to the south (10 to 40 feet per mile (ft/mi); Coates, 1981), which causes the oldest units to be exposed in the north and progressively younger units exposed to the south. Gentle east- and northeast-trending folds are also present, with dips of less than 1 degree (Coates, 1981; Wedel, 1932). Shale, sandstone, and conglomerate of the Oneonta Formation in the northern part of the study area are overlain by sandstone, siltstone, and shale of the Sonyea Group, which, in turn, are overlain by siltstone and shale of the West Falls Group in the southern part of the study area. Sandstone becomes more prevalent in the eastern part of the study area whereas shale and siltstone are prevalent in the western part (Coates, 1981). The Marcellus Shale, a natural gas resource, is present at depths of about 5,000 ft where the Susquehanna River exits Broome County at the New York/ Pennsylvania border and at depths of about 3,000 ft where the Susquehanna River enters Chenango County from Delaware County.

\section{Spatial Distribution of Glacial and Holocene Deposits}

Glacial-drift deposits of Pleistocene age blanket bedrock over much of the region. The glacial drift is broadly divided into (1) stratified deposits of ice-contact and non-ice-contact fluvial, deltaic, and lacustrine origin that are present largely within valleys (also referred to as "valley-fill deposits") and (2) till, which is an unsorted mixture of sediments (clay-toboulder ) deposited directly by glacial ice. Till is the dominant deposit on the hillsides of the upland area (plate 1) and is locally present in valley areas. Maximum thicknesses of stratified drift and till are about $300 \mathrm{ft}$ and $250 \mathrm{ft}$, respectively.

Stratified-drift in the Susquehanna River valley was largely deposited during deglaciation of the area, which occurred between about 17,000 and 15,000 years ago (Braun, 
2002, 2006c; Fleisher, 1986a, b). The distribution of coarseand fine-grained stratified deposits on the surface and in the subsurface of the Susquehanna valley (figs. $2-6$, plate 1) is indicative of the mode and rates of deglaciation (Koteff and Pessl, 1981; MacNish and Randall, 1982; Fleisher, 1986a, 1986b; Fleisher, 1993). Fleisher (1986b, 1993) characterized deglaciation in the Susquehanna River Basin immediately north of the study area as active ice retreat (backwasting) with local stagnation (downwasting) of the ice tongue caused by topographic controls in an environment of nearly ubiquitous proglacial lakes.

Holocene (post-glacial) deposits are mostly floodplain alluvium and alluvial fans within the valleys. Alluvial deposits are narrow where glacial meltwaters and, more recently, the Susquehanna River have incised into former ice-marginal positions and widen where the river crosses proglacial lake plains. Scully and Arnold (1981) identified four terrace levels of Holocene alluvium.

\section{Stratified-Drift Deposits Associated with Stagnation-Zone Retreat of Active Ice in the Susquehanna River Valley}

The prevailing concept for deglaciation in the northeastern United States is the retreat of active ice, fringed by a narrow, but variable, zone of stagnant ice at the ice margin (Koteff and Pessl, 1981). This "stagnation-zone" mode of retreat is marked by periods of comparatively rapid retreat punctuated by periodic pauses in the position of the ice margin. In many large valleys the pauses are marked by deposition of characteristic suites of deposits (morphosequences) coarse-grained stratified sediments at the ice margin with progressively finer-grained proglacial lake sediments extending downvalley to the previous ice-margin position. If the ice margin remained at a location long enough, coarse-grained meltwater sediments or outwash accumulated up to the lake surface and prograded downvalley over fine-grained sediments. Long pauses in ice retreat result in morphosequences with extensive downvalley outwash plains, whereas short pauses may result in limited morphosequences with limited outwash or small kame deltas. Periods of rapid ice retreat result in deposition of mostly fine-grained lacustrine deposits. Figure 7 is a schematic illustration of two such morphosequences deposited in association with proglacial lakes, which were characteristic of the study reach of the Susquehanna River valley.

Long-lived ice-margin positions are characterized by deposition of coarse-grained ice-contact deposits within the stagnant-ice zone (kame sand and gravel, kame terraces, and esker landforms). Meltwater discharge from stagnant ice into proglacial lakes resulted in deposition of progressively finergrained sand, silt and clay with distance from the ice (predominantly lacustrine sands and silts). Active ice supplied sediment to the ice margin, and as stagnant ice melted, outwash sand and gravel was deposited over and around ice blocks on the downvalley side of the ice-contact deposits. These outwash deposits typically are pitted closest to the ice margin where residual ice was buried by sediments and eventually melted out. The highest altitudes within morphosequences are typically at the head of the outwash deposits (fig. 7). Downvalley of the stagnant ice, if meltwater and sediment volume was sufficient, outwash sand and gravel prograded as deltaic topset beds into the lakes or only as outwash on drained proglacial lakebeds. Kame deltas along valley walls also mark sediment deposition into a proglacial lake near an ice margin position.

During periods of steady ice-margin retreat, meltwater was impounded by the previous downvalley morphosequence or some other downvalley base-level control; sedimentation was dominated by fine-grained materials (fine sand, silt and clay) in this environment. Coarse-grained sediments in these valley reaches are largely limited to discontinuous subaquatic fans, deposited beneath fine-grained lacustrine sediments at or near the bedrock surface from ice tunnel discharges of meltwater into the lake (fig. 7; Randall, 2001, p. B9).

Eight ice-marginal positions of different degrees of development were interpreted from the distribution of stratified drift in the study area (D. Braun, Bloomsburg University (retired), written commun., 2011) and are outlined on plate 1 and figure 8. Two of the margins indicate possible readvances. Most icemarginal positions are situated upvalley of either valley constrictions or abrupt changes in valley geographic orientation. Braun (Bloomsburg University (retired) written commun., 2011) has estimated duration of ice-marginal positions on the order of years to decades in the Susquehanna Basin south of the study area. Fine-grained deposits indicate that proglacial lakes existed downvalley of nearly every ice margin.

The interpreted margins, numbered from south (oldest) to north (youngest), with the exception of Margin 6, are described below and depicted on figure 8 and plate 1 :

- Margin 1 is delineated at South Windsor, upvalley of ice-contact or kame sand and gravel deposits (including an esker) that extend southward into Pennsylvania. These deposits are present as high as $200 \mathrm{ft}$ above the current floodplain and represent the stagnant-ice part of the morphosequence.

- Margin 2 is tentatively defined by a kame delta that was mapped by Cadwell (1972) at Damascus, N.Y. and by deposits interpreted as kame sand and gravel on the opposite (west) side of the valley. It represents a comparatively short-lived ice-margin position because sediment accumulation is limited.

- Margin 3 also is defined by a kame delta that was mapped on the east side of the valley by Cadwell (1972) and is immediately south of the umlaufberg (an isolated bedrock hill within a valley) at East Windsor. This kame delta is larger than the kame delta at ice margin 2, and thus was likely a longer-lived ice-margin position. 


\section{EXPLANATION}

(figures 2-6)

al Alluvium-Postglacial river and stream floodplain deposits consisting predominantly of stratified silt and clean to silty sand, commonly with some gravel at the base of the deposit. Thickness as much as 15 to 25 feet ( $\mathrm{ft}$ ) in the Susquehanna River valley and large tributary valleys. Typically underlain by stratified glacial deposits in main valleys and by till in narrow upland valleys.

alf1 Alluvial fan-Fan-shaped accumulations of stratified silty sand and gravel, deposited by tributary streams where they enter the Susquehanna River valley and large tributary valleys. The fans are typically underlain by outwash or ice-contact sand and gravel derived, in part, from the tributary drainage area associated with the alluvial fan. Large alluvial fans began forming as soon as the valley was ice-free, deposited over glacial deposits and graded to a former high-altitude floodplain.

osg Outwash sand and gravel—Stratified, well-sorted sand and gravel deposited by glacial meltwater streams as outwash terraces, topset beds of deltas near the receding ice front, and as valley-train outwash (originally spanning the width of the valley) away from the ice front. Outwash in the Susquehanna River valley is subdivided into two general categories on the basis of height above present river level and thickness of the deposits. High outwash deposits have upper surfaces greater than or equal to $30 \mathrm{ft}$. above river level and are relatively thick deposits ( $20 \mathrm{to} 70 \mathrm{ft}$.) unless reworked and eroded. High outwash deposited close to the ice margin is pitted with kettle holes. Low outwash is defined by upper surfaces less than $30 \mathrm{ft}$. above river level and thicknesses of approximately 5 to $15 \mathrm{ft}$.

ksg Kame sand and gravel-Ice-contact deposits of poor- to well-sorted sand and gravel that was deposited beneath, within, or on top of melting glacial ice. Includes kame terraces (along valley walls) in valley segments where active ice retreat was steady; eskers and hummocky terrain in valley areas of ice stagnation (ice marginal positions) Extreme variability in sorting, grain size, and thickness of individual beds. Moderate to high permeability, high permeability especially in coarse, well-sorted zones. Deposits situated at low altitude (below the valley floor and with favorable characteristics (high permeability) form localized unconfined or confined aquifers.

Is Lacustrine sand-Glaciolacustrine deposits of well-sorted sand that were deposited into proglacial lakes in closer proximity to sources of sediment or a higher energy environment than the glaciolacustrine silt and clay deposits. May fill valley depressions where stagnant ice blocks melted. Limited to relatively small areas in the north. Subsurface distribution of lacustrine sand based on well-log descriptions by local well drillers.

SS Lacustrine sand, silt, and clay-Glaciolacustrine deposits of thinly to massively bedded silt, fine to very fine sand, and some clay. Deposited as lake-bottom sediments (bottomset beds) in proglacial lakes that formed as result of the temporary dams created by downvalley ice-marginal deposits such as high-outwash valley trains and kame moraine and kame delta deposits. Thicknesses can reach as much as $275 \mathrm{ft}$. These deposits have low permeability and form the principal confining unit in the Susquehanna River valley-fill aquifer system.

$\mathrm{t} \quad$ Till-Thick (greater than or equal to $30 \mathrm{ft}$ ), unsorted, unstratified mixture of clay, silt, sand, gravel, and boulders deposited beneath the ice as lodgment till during a glacial advance or at the edge of the ice sheet by melting ice as ablation till during a pause, or retreat, of the ice front. Thickness 20 to $250 \mathrm{ft}$. Very low permeability, but may yield adequate amounts of water for domestic use to large-diameter dug wells where sufficiently saturated or where gravelly zones of higher permeability exist. Found mostly in uplands and typically absent on the floor of the Susquehanna River valley.

Bedrock-Mostly Devonian-age shales, siltstones, and sandstones. Beds are gently folded and have a regional dip to the south from 10 to 40 feet per mile.

Well-Site name is assigned by the U.S. Geological Survey. BM - Broome County, CN - Chenango County; number following county abbreviation is the sequential well number.

$$
\text { r. }
$$

Passive seismic (H/V) survey site-Length of dashed line indicates interpreted depth to bedrock. H/V is the ratio of the horizontal to vertical components of the ambient seismic frequency spectrum at a site, which can be used to estimate sediment thickness.

$\nabla$ Depth to water in well, in feet-Measured by driller and recorded on well-log form submitted to the New York State Department of Environmental Conservation. 


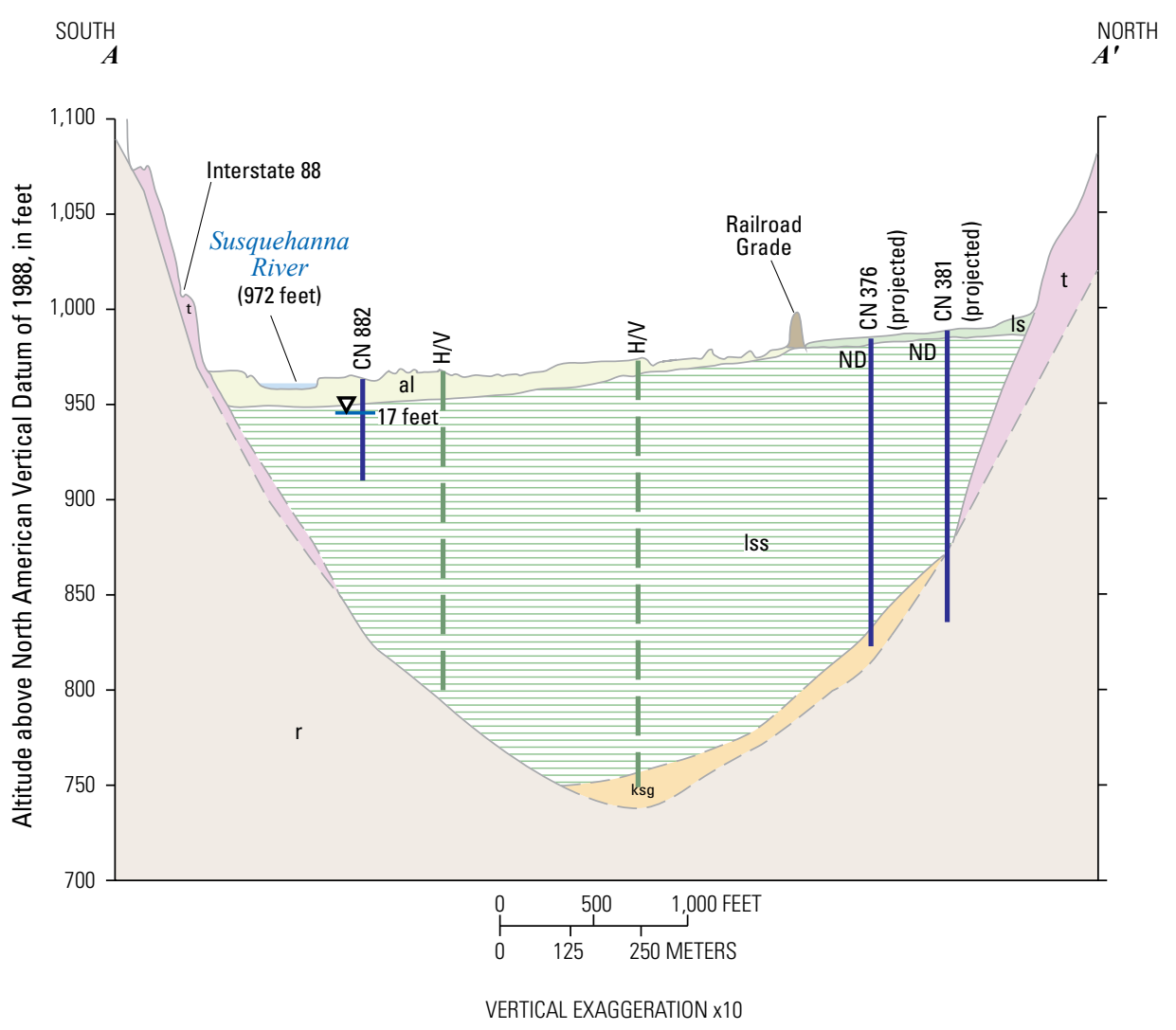

Figure 2. Geohydrologic section $A-A^{\prime}$ east of Bainbridge, Chenango County, New York. 
路的

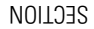

NI ONG9

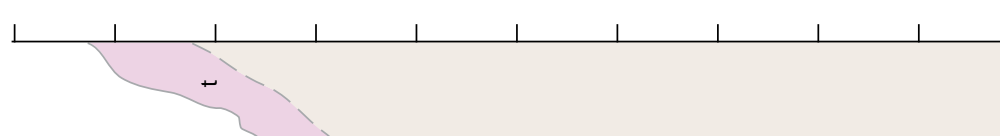

(рәาวәㅇd)

6ILINJ

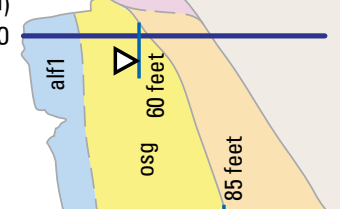

兽

NOILJJS

$\mathrm{NION \exists G}$

leginJ
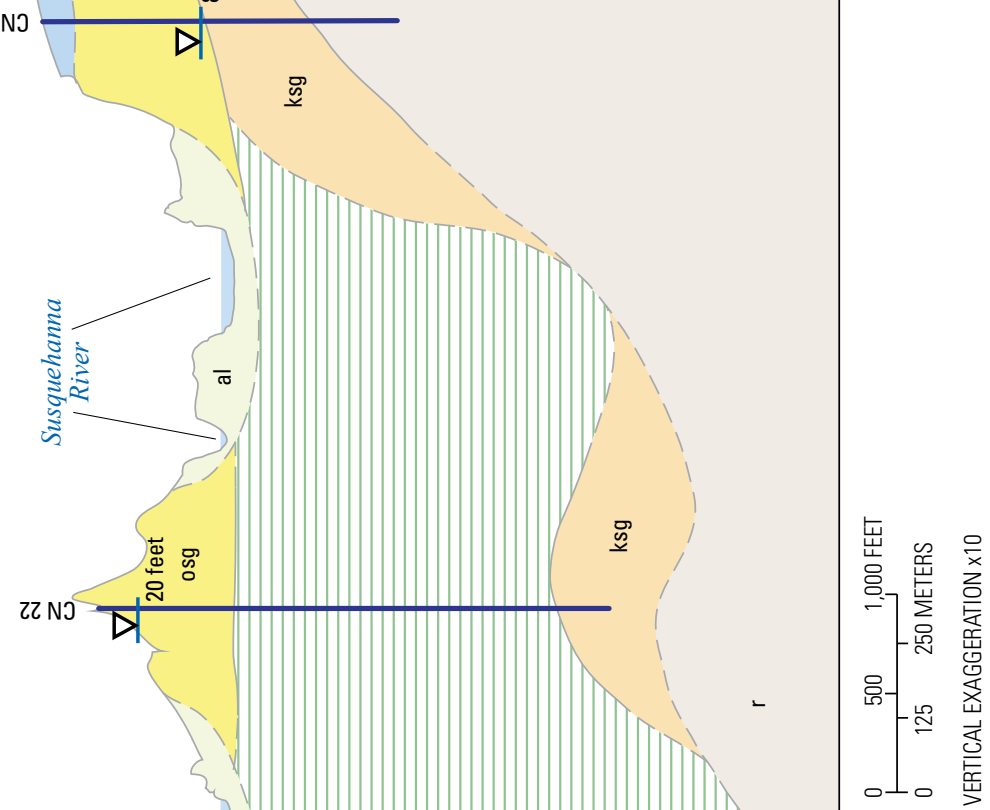

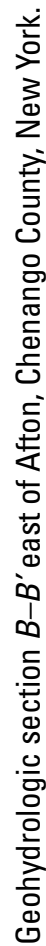

퐁

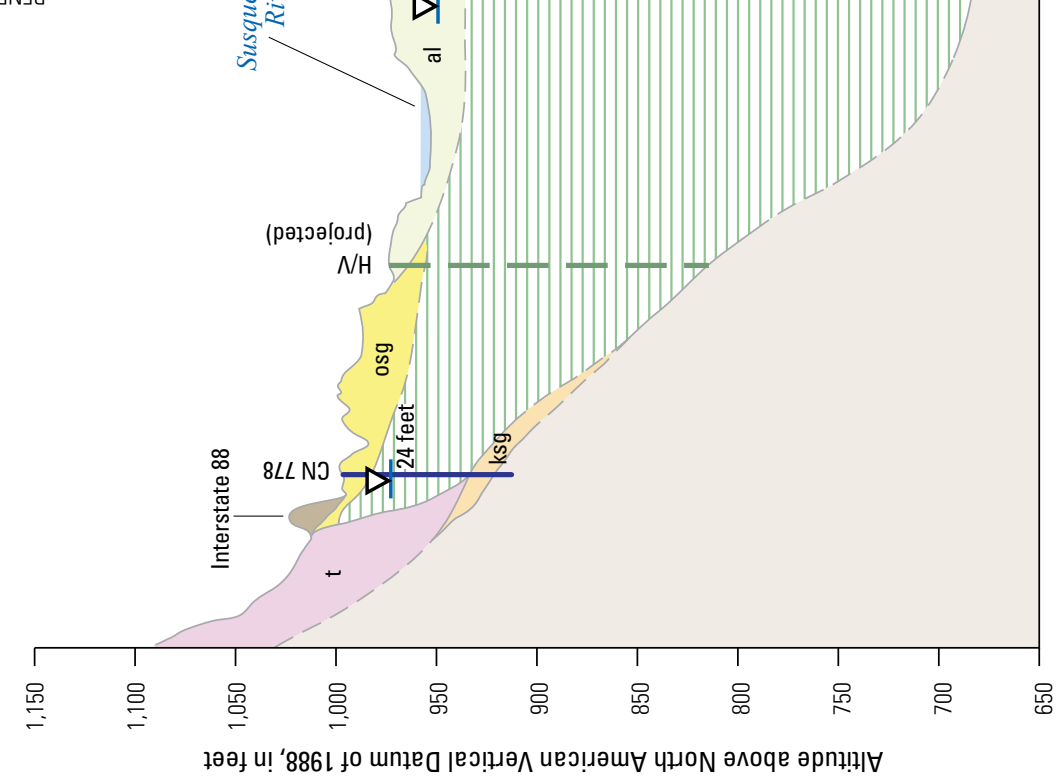

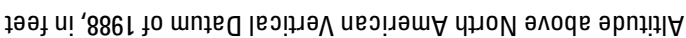

ํㅗㄴ 
EAST

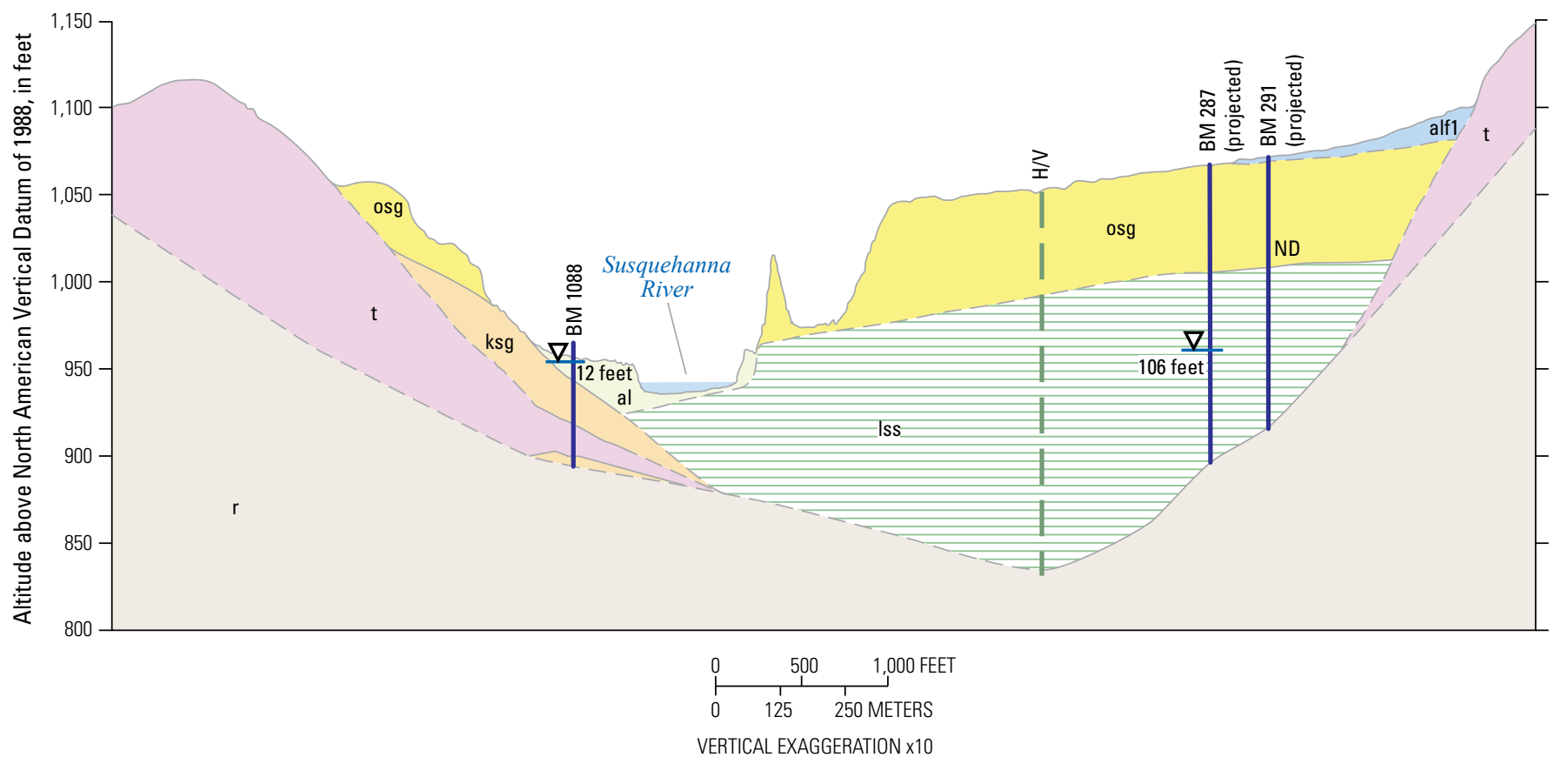

Figure 4. Geohydrologic section C-C' south of Harpursville of Broome County, New York.

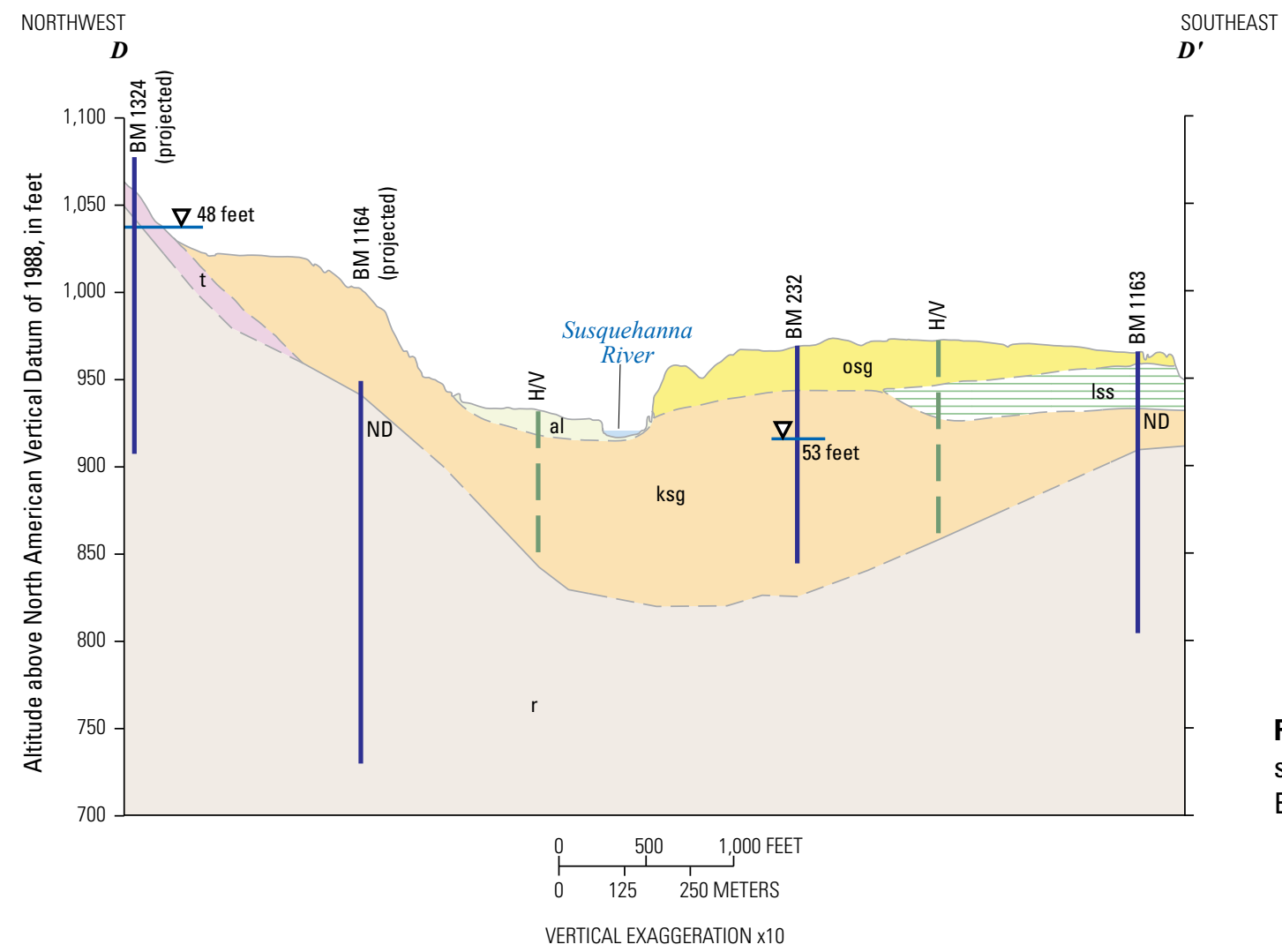

Figure 5. Geohydrologic section $D-D^{\prime}$ at Ouaquaga, Broome County, New York. 


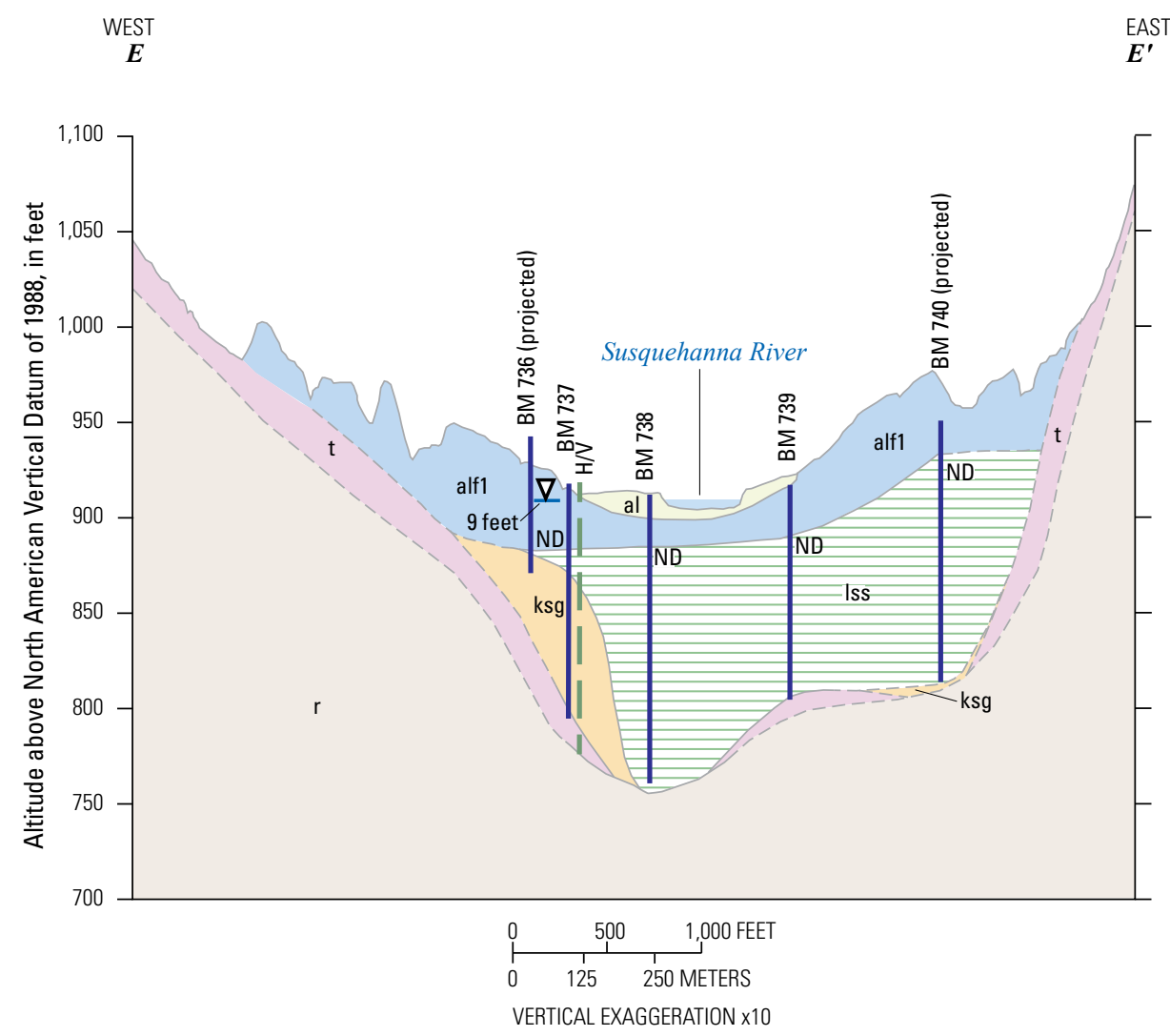

Figure 6. Geohydrologic section $E-E^{\prime}$ at Windsor, Broome County, New York.

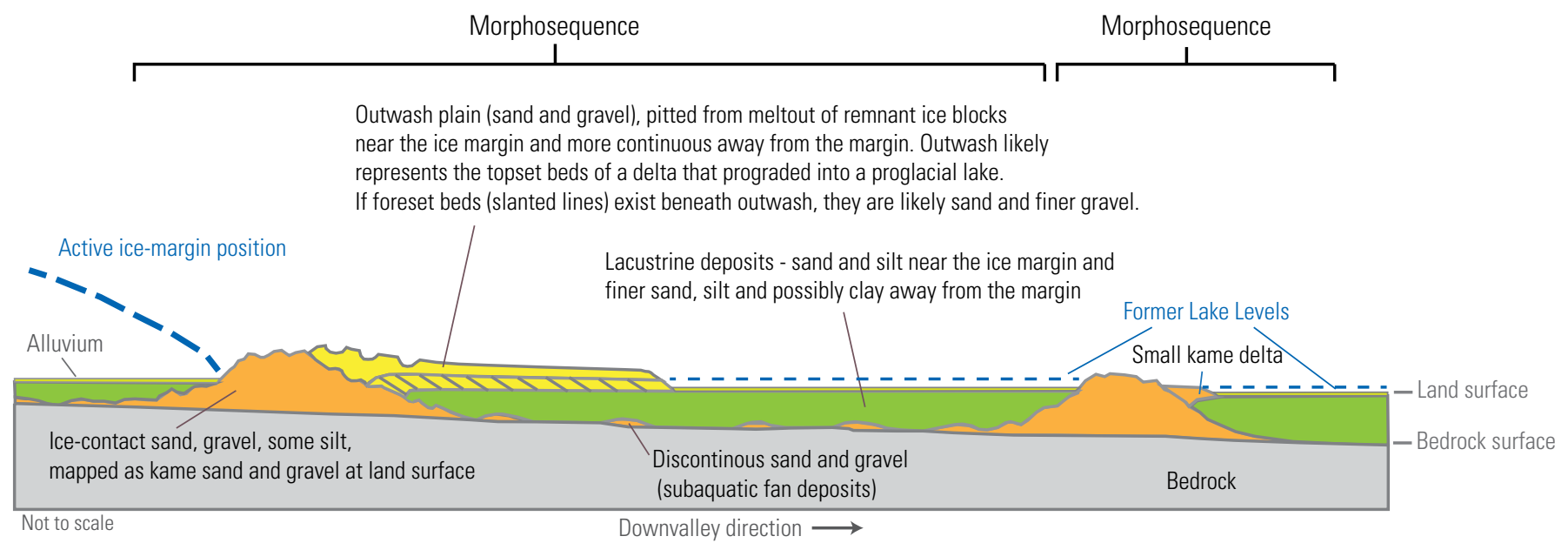

Figure 7. The longitudinal valley geologic section morphosequences that represent long (left) and short (right) pauses in the retreat of the ice margin. 


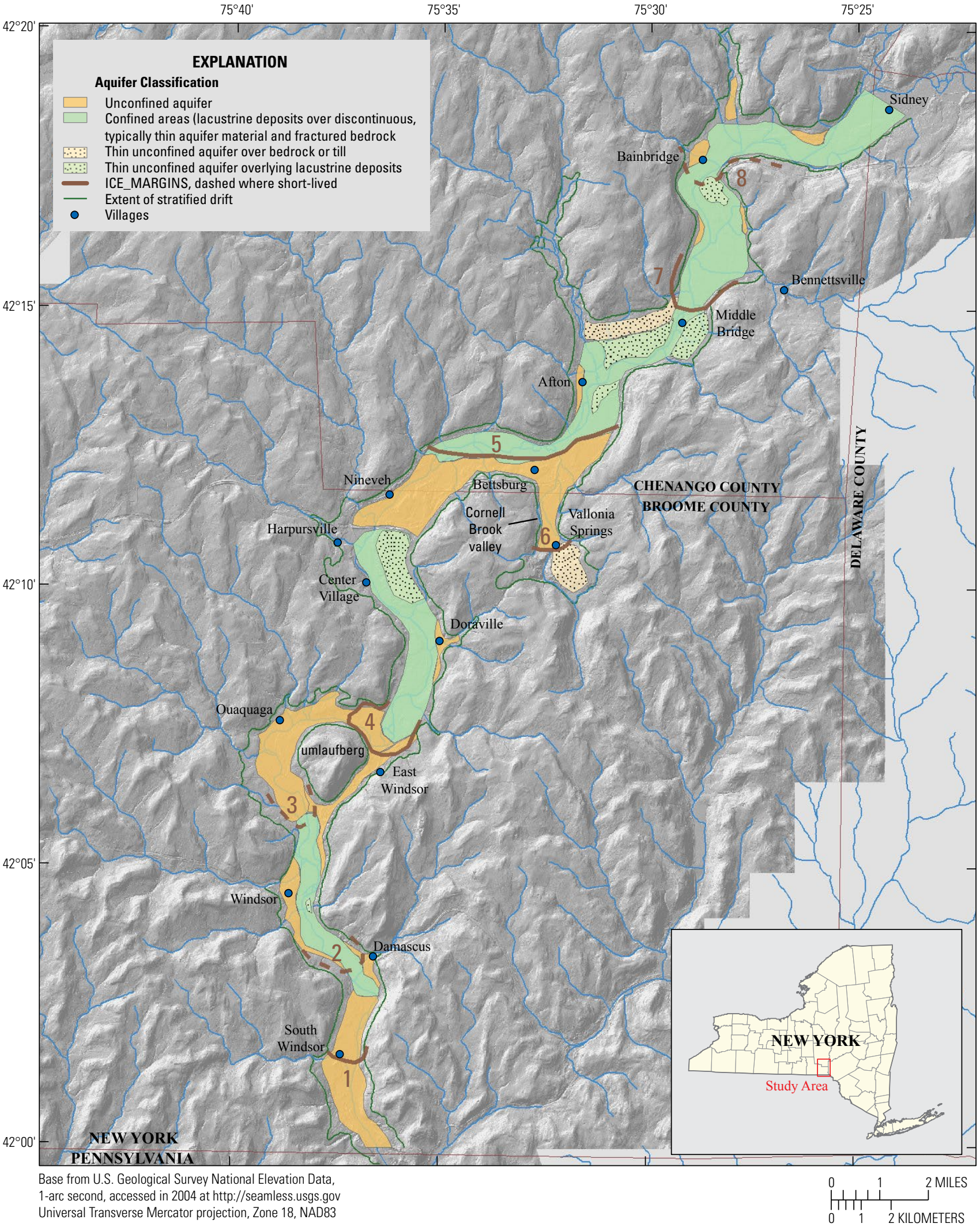

Figure 8. Distribution of aquifer types and settings within the Susquehanna River valley-fill aquifer system, eastern Broome and southeastern Chenango Counties, New York. 
- Margin 4 is at the upvalley (northeast) side of the umlaufberg at East Windsor and is characterized by kame sand and gravel in the valley reaches around each side of the umlaufberg. The east-side valley is short, straight, and narrow, with no present-day stream. It contains an esker landform feature that leads to the kame delta of margin 3, whereas the west-side valley circumscribes most of the umlaufberg, contains the Susquehanna River, and is characterized by smoothed kame sand and gravel hills with remnants of lateglacial or post-glacial outwash and Holocene alluvium. One well (BM 232) penetrated $123 \mathrm{ft}$ of sand and gravel in the center of this valley reach (plate 1, fig. 5).

- Margin 5 is the longest-lived margin with the most complete morphosequence in the study area, which extends nearly 6 miles downvalley. Kame sand and gravel is present on the south side of east-west oriented reach of the Susquehanna valley from east of Bettsburg to Nineveh (plate 1) and marks the icestagnation zone. Kame sand and gravel transitions to pitted outwash sand and gravel between Nineveh and Harpursville, and to outwash sand and gravel from Harpursville south to margin 4. The outwash deposits overlie lacustrine sediments throughout this reach (fig. 6). Meltwater impounded in proglacial lakes upvalley of this ice margin subsequently overtopped and downcut through the outwash creating several terrace levels above the present-day floodplain.

- Margin 6 is represented by a well-preserved upland kame delta above Vallonia Springs in the Cornell Brook valley about 1.5 miles from the Susquehanna River valley at Bettsburg. The top altitude of this southward-draining delta is nearly $400 \mathrm{ft}$ above the top altitude at margin 5, which indicates that margin 6 must be older than margin 5 . This delta must have been fed chiefly by meltwater from the east side of the Susquehanna River valley to the north, flowing through subglacial channels (locally preserved as an esker). The altitude of the highest part of the delta (1472 ft) approximates the lake altitude, which requires that the meltwater head in the Susquehanna River valley to the north was at least that high at the time - so the ice tongue in the Susquehanna River valley to the west and south of Bettsburg must have remained active and solid for some distance, perhaps well south of Nineveh. Eventually, continued melting opened channels and crevasses in the ice tongue that lowered the local meltwater head, initiating deposition at a margin to the south (A. Randall, U.S. Geological Survey (retired), written commun. 2012).

- Margin 7 is demarcated by high terraces of highly pitted to non-pitted outwash sand and gravel with limited kame sand and gravel between Middle Bridge and Afton. These deposits were originally continuous across the valley, effectively impounding meltwater upvalley until meltwaters and the Susquehanna River incised the current channel. The east-side terrace is mostly non-pitted, but is apparently mantled by a thin layer of till (U.S. Department of Agriculture, 2008; http://soildatamart.nrcs.usda.gov). Till overlying outwash indicates at least a minor readvance of the ice front. Most of the west-side deposits are mapped as heavily pitted outwash sand and gravel because the flat topped surfaces slope consistently to the west-southwest. The southern one-half of the west-side deposits have been eroded to a lower terrace level with remnants extending to the south side of Afton. Kame sand and gravel is mapped across a limited area in the northeast corner of the west-side deposits. The sediments overlie bedrock in this area, but do not extend across the valley. Well logs from the center of the valley near the margin indicate only thick lacustrine deposits. The absence of well-developed kame sand and gravels at this margin may indicate that it represents a readvance of the ice front (A. Randall, U.S. Geological Survey (retired), written commun., 2012).

- Margin 8 represents a short-lived ice-margin position that may also represent a local readvance of the ice front. The surface expression of the margin consists of a few isolated hills of outwash (?) sand and gravel and a plain of thin outwash $(\sim 10 \mathrm{ft})$ south of Bainbridge. Wells in the area around the hills penetrated 50-100 ft of silty to sandy lacustrine deposits with intervals of sand and gravel. One well penetrated $60 \mathrm{ft}$ of gravel beneath the lacustrine deposits. Sediments along the west side of the valley immediately downvalley of this margin are coarse, including sand and gravel beneath till along the lower valley wall and at least $40 \mathrm{ft}$ of gravel beneath the floodplain just west of the southernmost hill.

\section{Till Deposits in the Uplands}

Till consists of a mixture of poorly sorted clay-to-boulder size sediment that was deposited directly by the glacier. Till is the dominant glacial deposit in the upland areas and is also common along the lower flanks of hillsides and extends below the valley floor in some places (figs. 2-4). The asymmetry of till deposits on hills ("till shadows", Coates, 1966; Braun, 2006c) is evident in the uplands of the study area-comparatively thin on the hilltops and on the north and northeast hillsides that faced the flow of the ice, and thicker (as much as $250 \mathrm{ft}$ ) on the lee (south-southwest) hillsides (plate 1). In tributary valleys perpendicular to ice flow, stream courses are skewed to the southwest because of the till shadows. Till shadows are not present in major valleys where ice tongues eroded the valley walls (Randall, 2001), such as at the outside of bends in the valley or at bedrock spurs. In addition, low till 
hills of different origin have been noted in primarily northsouth-oriented tributary valleys. The small hills or lobes have been interpreted as a result of downslope movement of till from hillside hollows into the tributary valley during periglacial periods (concavo-convex landforms; King and Coates, 1973) and as recessional moraines, marking upland stillstands of the ice margin (Braun, 2002, 2006c).

\section{Holocene Deposits}

Holocene deposits include alluvium, alluvial fans, and peat muck or wetland deposits (plate 1). Alluvium, or floodplain deposits are limited to valley bottoms, and are most extensive within the Susquehanna River valley except in areas where the river has incised a channel into thick glacial deposits. Scully and Arnold (1981) described the presence of alluvium at the north end of the study area, which chiefly consisted of silt and fine-to-medium grained sands underlain by gravel. Alluvium in tributary valleys typically is described as silty gravel or gravelly silt. Thicknesses range from 13 to $16 \mathrm{ft}$ (Scully and Arnold, 1981) to as much as $25 \mathrm{ft}$.

Alluvial fan deposits form where tributary streams enter larger valleys and deposit their sediment load during flooding events. Alluvial fan sediments range in size from silt to gravel. In this study area, they are divided into two categories: alf 1 , generally large older deposits that were graded to a higher late-glacial or post-glacial river-valley level, and more recent fan deposits (alf 2) that grade to the lower present-day floodplain level. The alf 2 deposits are isolated small fans as well as larger fans where tributary streams have incised 25 to $30 \mathrm{ft}$ into the older alf1 fan deposits and redeposited that material as a more recent fan below and beyond the older fan.

Peat and muck deposits (primarily organic material) are limited within the study area and typically form in areas of poor drainage such as low areas in tributary valleys constricted by till hills or in kettleholes in pitted-outwash areas. These deposits are generally thin (less than $20 \mathrm{ft}$ thick).

\section{The Susquehanna River Valley-Fill Aquifer System}

The Susquehanna River valley-fill aquifer system is composed of unconfined and confined aquifers, which are broadly delineated in figure 8 . Definition of aquifer type and distribution is based on interpretation of surficial geology, well logs, LiDAR altitude data (plate 1), and previous studies in the region that coincide with the morphosequence conceptual model (fig. 7) and interpreted ice-margin positions (plate 1, fig. 8). In general, long pauses in the retreat of glacial ice allow for the accumulation of coarse-grained stratified drift in the valley, whereas steady, rapid retreat of glacial ice produces predominantly fine-grained deposits with limited, discontinuous coarse-grained deposits beneath or along the edges of the fine-grained deposits. Therefore, the inferred water-resource potential within different valley reaches increases with the inferred duration of each ice-margin position.

A schematic geologic section along the axis of a valley (fig. 9) illustrates the ice-margin-based conceptualization of aquifer occurrence within the Susquehanna River valley. In

\footnotetext{
Alluvium or low, thin outwash-

Generally, thin, silty unconfined aquifer - tapped by few wells in the study area. If underlain by ice-contact sand and gravel, especially near the Susquehanna River, there is potential for high well yield through induced infiltration of river water.
}

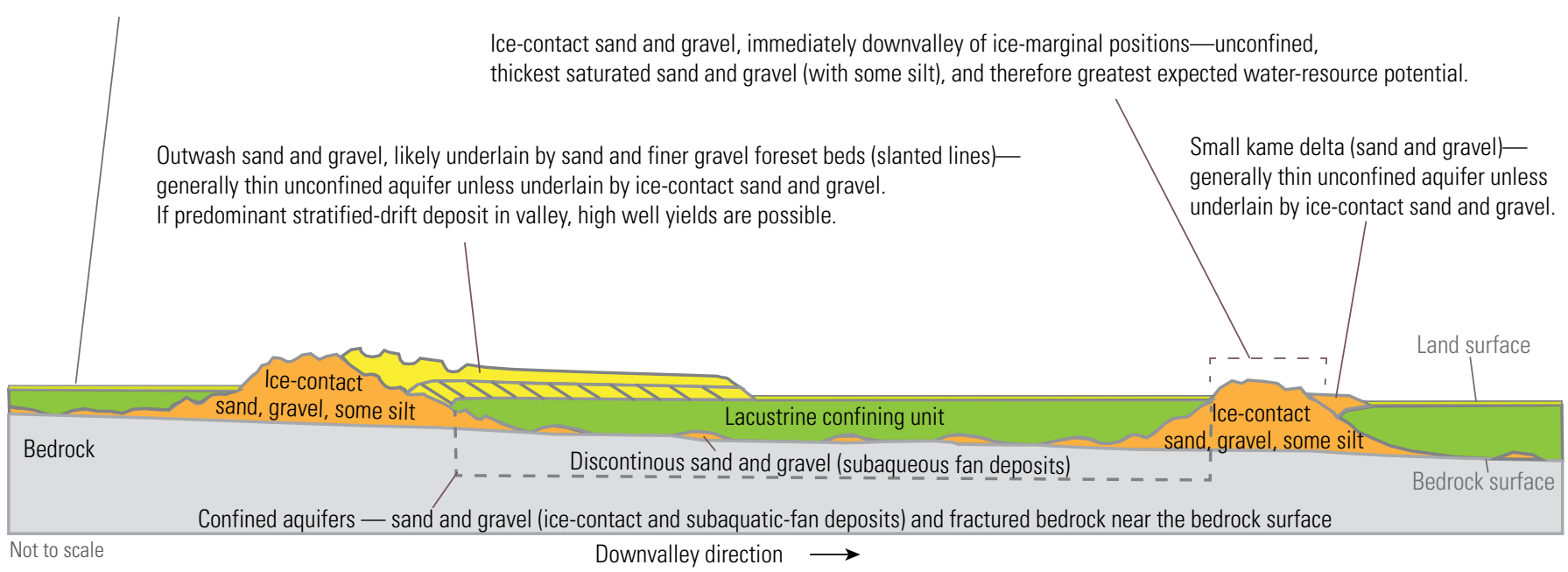

Figure 9. Longitudinal valley geologic section aquifer types and occurrences in relation to the morphosequence distribution of stratified drift (see fig. 7). 
short, the most extensive aquifers are associated with thick ice-contact sand and gravel deposits associated with longlived ice-margin positions. These deposits are unconfined where exposed at land surface, and confined where they extend upvalley or downvalley beneath fine-grained lacustrine deposits. Other coarse-grained stratified drift such as outwash and kame deltas are associated with thin, unconfined aquifers of limited water-resource potential because they are typically high above the valley floodplain (figs. 8-9). Large alluvial fans may grade downward into generally coarse-grained inwash from upland drainage areas or ice-contact deposits, and therefore, constitute local unconfined aquifers (plate 1, fig. 8 at Windsor and Bainbridge). A thin aquifer within silty floodplain alluvium and perhaps low outwash deposits (fig. 9; not depicted in fig. 8) is limited in water-resource potential-few domestic wells are completed in it. Substantial water-resource potential exists, however, if gravelly zones at the base of the alluvium are in hydraulic connection with the Susquehanna River such that pumping wells can induce infiltration of water from the river into the alluvium.

\section{Areas of Favorable Water-Resource Potential}

The aquifer distribution in figure 8 provides a basis for inferring water-resource potential within the Susquehanna River valley-fill aquifer system. Areas of extensive, thick unconfined aquifers are the most potentially favorable for water-resource development. They include three principal reaches mostly within Broome County (fig. 8). The southernmost unconfined aquifer occupies the comparatively straight, narrow valley reach that includes ice margin 1 from the New York-Pennsylvania border to about a mile north of South Windsor. There is little subsurface data in this area. The next reach is around the west side of the umlaufberg at East Windsor between ice margin positions 3 and 4 . One well in the middle of the valley (BM 232, fig. 5) was completed in $123 \mathrm{ft}$ of sand and gravel. Water-resource potential of the valley reach on the east side of the umlaufberg is likely limited-it contains no through-flowing stream, is higher in altitude than the present-day (2012) floodplain, and is narrow. The third reach, along the Broome-Chenango County border, is associated with ice margin 5 (kame sand and gravel from Bettsburg to Nineveh) and includes outwash in the Cornell Brook Valley north of ice margin 6 . This reach has the greatest potential because of the extensiveness of these unconfined aquifer deposits, which likely extend to the north side of the valley (north of margin 5 on fig. 8), confined beneath lacustrine deposits. Several wells are completed in at least 60 to $100 \mathrm{ft}$ of sand and gravel, but no well logs obtained during the study extend to bedrock.

Local unconfined aquifers depicted on figure 8 include kame deltas, isolated kame sand and gravel deposits, and alluvial fans along valley walls. The kame deltas mark short-lived ice margins 2 and 3, whereas the others are not associated with interpreted ice margins. No well data are available for the kame deltas (one serves as a gravel pit), so the thickness of saturated aquifer material is unknown. Well data from public supplies at a few of the other areas indicate that well yields of as much as 300 gallons per minute are possible.

Thin unconfined aquifers over bedrock or lacustrine deposits shown on figure 8 can be areally extensive and striking landforms (outwash, pitted outwash and a kame delta), but water-resource potential is likely limited because of their height above the current floodplain and limited saturation. These thin aquifers are associated with ice margins 5, 6, 7, and 8. Springs at the base of the kame delta at ice-margin 6 are used for public supply, but otherwise, domestic wells (typically completed in bedrock beneath these deposits) are the norm.

Confined aquifers are likely discontinuous beneath the extensive lacustrine deposits indicated in figure 8. They include (1) kame sand and gravel adjacent to surface exposures of the same material either at ice-margin positions or at smaller surface exposures, (2) subaquatic fan deposits, which were deposited (discontinuously) from meltwater tunnels discharging from the ice into proglacial lakes during periods of rapid retreat (Randall, 2001, p. B9), and (3) fractured bedrock near the top of bedrock. Domestic wells use this aquifer, but no high-capacity wells draw from it. Water-resource potential is favorable, particularly if substantial thicknesses of confined, coarse sediments exist adjacent to large unconfined kame sand and gravel deposits at the long lived ice-margin positions described above. Ultimately, the resources associated with these deposits are dependent on hydraulic connection with unconfined aquifers that can recharge the confined aquifers.

\section{Sources of Groundwater and Groundwater Flow}

Precipitation that infiltrates directly or indirectly into the subsurface (recharge) is the ultimate source of groundwater throughout the study area. Groundwater exits the flow system (1) through diffuse subsurface discharge to tributary streams in the uplands and to the Susquehanna River in the main valley, (2) as discharge from springs, where groundwater flow is directed to land surface at topographic low points or along the contact of permeable sediments that overlie impervious sediments such as sand and gravel on top of bedrock, till, or glaciolacustrine deposits, (3) evapotranspiration, and (4) as groundwater flow downvalley within the Susquehanna River valley-fill aquifer beyond the study area (fig. 10).

Recharge in upland areas is entirely from precipitation. Precipitation that is not lost to evapotranspiration either flows downslope as overland flow (or within macropores in the upper few feet of weathered till) or infiltrates downward into till or bedrock. In both cases, water eventually moves down hillsides and discharges to streams or infiltrates into permeable valley-fill deposits. Where bedrock is mantled by thin, discontinuous till, a substantial fraction of precipitation may infiltrate downward as recharge to bedrock. Much of this water flows downslope within the upper 100-150 ft of fractured bedrock. 


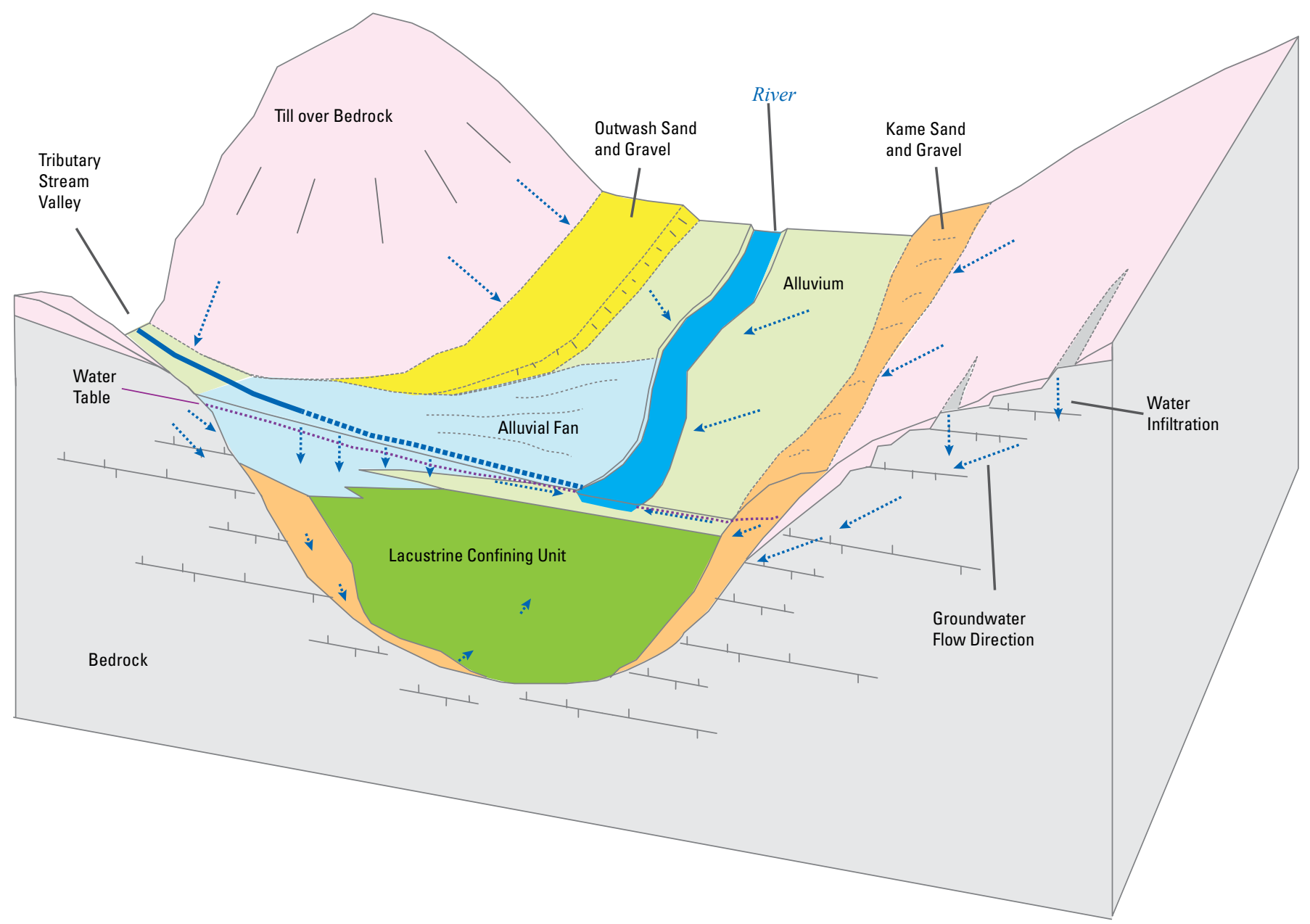

Figure 10. Conceptual block diagram of groundwater flow in the Susquehanna valley-fill aquifer system.

Where several tens to hundreds of feet of till blanket bedrock, recharge by downward infiltration to bedrock is exceedingly small per unit area.

Valley-fill aquifers receive recharge from direct infiltration of precipitation into permeable glacial deposits, but Morrissey and others (1988) have documented that recharge from upland sources can exceed that of direct precipitation. Upland sources of recharge include (1) groundwater flow to the valley from adjacent unchanneled hillslopes, and (2) infiltration of streamflow from tributaries as they cross alluvial fan deposits in the valley.

The Susquehanna River valley-fill aquifer system is a composite unconfined-confined system with the best interconnection of aquifers where extensive and thick unconfined aquifer sediments become confined beneath lacustrine confining units upvalley and downvalley of ice-margin positions (figs. 8-9). Deep confined aquifer areas beneath lacustrine confining units have uncertain interconnection with unconfined aquifers at ice-margin positions, along valley edges (kame sand and gravels or alluvial fans (Crain, 1966)) or with underlying fractured bedrock. Natural groundwater flow conditions in deep confined aquifer areas is exceedingly slow because recharge and flow from unconfined areas is limited by groundwater discharge through thick confining units. Some confined areas may have little or no connection with unconfined aquifers (fig. 9). The degree of interconnection with unconfined aquifers can be tested by pumping confinedaquifer areas and monitoring water levels in surrounding confined and unconfined aquifer wells. Pumping confined aquifer areas will increase groundwater flow rates and potentially induce additional recharge from hydraulically connected unconfined zones of the aquifer system.

Groundwater flow within shallow zones of the unconfined aquifer in the Susquehanna River valley is predominantly from the valley walls toward the river with a gentle downvalley component, dependent on local valley floor 
gradients and topography (fig. 10). Groundwater flow is likely most rapid within this part of the aquifer system, as direct groundwater recharge, and groundwater inputs from hillsides and streams that traverse alluvial fans must be conveyed to the river (under natural groundwater-flow conditions). A watertable map was not constructed as part of this study because few wells are finished in alluvium along the valley reaches underlain by lacustrine deposits (figs. 8-9) and most wells in unconfined aquifers are completed far below the water table.

\section{Groundwater Resources}

The Susquehanna River valley-fill aquifer is the only potential groundwater source of large municipal, commercial, or industrial supplies of the study area. Water-resource availability from ice-contact stratified drift or alluvium in most tributary valleys is limited because saturated thicknesses of these deposits are thin. The fractured bedrock aquifer can provide adequate water supply for low-density residential development in the uplands and in upland valleys.

\section{Current (2012) Groundwater Use}

Overall water-resource use is low because of the rural character of the study area. Usage is centered near villages that utilize either public-supply wells, springs, or domestic wells. Usage in the upland area consists of widely spaced domestic wells that tap the bedrock aquifer.

\section{Public Supplies}

There are 33 public-water supplies that utilize groundwater within the study area-3 community supplies and 30 small noncommunity supplies (U.S. Environmental Protection Agency, n.d.; http://oaspub.epa.gov/enviro/sdw_form_ v2.create_page?state_abbr=NY). The three community supplies serve the Villages of Windsor, Afton, and Bainbridge. All three villages are within the Susquehanna River valley and are situated on or adjacent to alluvial fans of large tributary streams. The alluvial fans overlie saturated sand and gravel (outwash or ice-contact deposits), which were noted earlier as favorable for water-resource development. Supply wells in these areas are reported to have yields of 100 to 350 gallons per minute. Induced infiltration of Susquehanna River water into these local aquifers is likely where coarse-grained sediments provide hydraulic interconnection between the river and wells. No records of other large-yield wells, or exploration for such wells, were obtained during this study.

The primary water source for the Village of Afton is spring water that discharges from the base of the kame delta in the Cornell Brook drainage (see plate 1). A supply well taps a confined area of the Susquehanna valley-fill aquifer system to supplement the water supply for Afton.

\section{Domestic Supplies}

Well permit data from NYSDEC indicate that most new domestic wells that are drilled in upland areas tap the fractured-bedrock aquifer. Wells completed in the Susquehanna River valley and major tributary valleys commonly tap thin permeable sand and gravel zones just above bedrock or a few feet into fractured bedrock. Many lowland areas of the Susquehanna River valley have little new development because most land continues to be used for agriculture- thus, most new wells are drilled in upland areas.

Well logs from the USGS National Water Information System (NWIS) database and from the NYSDEC well-permit program indicate that most domestic wells in the Susquehanna River valley are completed with open-ended casing (no well screen) in sand and gravel deposits or are cased to bedrock and completed as open-hole bedrock wells. Yields from most open-end-casing wells are sufficient to meet the owner's needs, but are only a small fraction of what could have been obtained by placing a well screen within the water-yielding sand and gravel.

Statistics of reported well yield from NYSDEC well permits were determined for wells categorized by landscape position and aquifer material (table1). Landscape positions include "valley" (Susquehanna River valley or major tributary valleys with stratified drift) or "upland" (including upland valleys containing mostly till) and aquifer material is either sand and gravel or fractured bedrock. Reported yields of zero were not included because cross-checking between database and original well permits in a subset of wells indicated that zero is the default value in the database field; in checked well-permit forms, the yield entry was absent as opposed to a zero value.

The data indicate that average reported domestic well yields from sand and gravel aquifers (in valleys) are about 65 percent higher than those of bedrock wells in either upland or valley settings. Bedrock wells in upland and valley settings have the same average reported yields. Higher bedrock well yields in valleys are generally observed because bedrock typically is completely saturated and can be overlain by saturated, permeable, valley-fill deposits. A 44-percent greater average bedrock penetration (about $40 \mathrm{ft}$ ) in upland wells than in valley wells may minimize any difference in reported well yield. Reported yields from drillstem testing (local drillers) are interpreted as general estimates-Williams and Eckhardt (1987) indicate driller air-blown well yield estimates may underestimate the yield of wells completed in highly permeable aquifer material and overestimate the yield of wells completed in aquifers of low permeability.

\section{Considerations For Aquifer Protection}

Aquifer protection in the study area is a topic of public concern in relation to the potential for natural gas drilling in this part of New York. Aquifer protection efforts likely 
Table 1. Statistics of well yields for wells in upland and valley areas, eastern Broome and southeastern Chenango Counties, New York. Well yields reported by drillers, New York State Well Permit Program (2000-10).

\begin{tabular}{|c|c|c|c|}
\hline \multirow[t]{2}{*}{ Reported well-yield statistic } & \multirow{2}{*}{$\begin{array}{c}\text { Upland wells } \\
\text { Bedrock } \\
(285 \text { wells }) \\
\text { (gallons per minute) }\end{array}$} & \multicolumn{2}{|c|}{ Valley wells } \\
\hline & & $\begin{array}{c}\text { Bedrock } \\
\text { (48 wells) } \\
\text { (gallons per minute) }\end{array}$ & $\begin{array}{c}\text { Sand and gravel } \\
\text { (29 wells) } \\
\text { (gallons per minute) }\end{array}$ \\
\hline Average & 12 & 12 & 20 \\
\hline Maximum & 60 & 40 & 70 \\
\hline 75th percentile & 15 & 15 & 20 \\
\hline Median & 11 & 12 & 18 \\
\hline 25th percentile & 7 & 10 & 15 \\
\hline
\end{tabular}

will focus on currently (2012) used resources. Information provided in this report may help managers prioritize protection of largely unused aquifers whose characteristics suggest that they are capable of providing large public or commercial water supplies.

\section{Upland Watersheds that Contribute Water to the Susquehanna Valley-Fill Aquifer}

As discussed in the section "Sources of Groundwater and Groundwater Flow", infiltration (loss) of streamwater as tributary streams cross alluvial fans in the main valley is a source of recharge to the valley aquifer. If water quality in those streams is compromised by activities in the upland watershed, groundwater quality in the valley may, in turn, be degraded; therefore, the maintenance of good water quality in the upland watersheds that are the source of these streams is an important aspect of protecting the Susquehanna River valley-fill aquifer system. This is particularly important at locations such as Windsor, Afton, and Bainbridge, where public-supply wells tap deposits that underlie alluvial fans. Public-supply springs, used by the Village of Afton, likewise derive some water from adjacent uplands. These contributing upland areas are delineated on the map plate (plate 1). Hillsides adjacent to the Susquehanna River valley also provide recharge to the aquifer through surface runoff or subsurface flow that seeps into the aquifer along the edges of the valley (fig. 10).

\section{Upland Areas of Thin Till over Bedrock}

Groundwater in bedrock in upland areas is far more susceptible to contamination in areas with thin till or exposed bedrock than where till is several tens of feet thick. Contamination in these areas would migrate downslope through shallow fractures in the upper 100-150 ft of bedrock; therefore, avoidance of activities that could potentially degrade groundwater quality in areas of thin till or exposed bedrock (plate 1) in favor of areas with thick till (greater than $50 \mathrm{ft}$ ) can minimize adverse effects on nearby domestic wells.

\section{Summary}

The Susquehanna River valley-fill aquifer system and associated water resources in eastern Broome and southeastern Chenango Counties, New York, were investigated given the potential for natural-gas resource development in the region. The aquifer system was delineated and characterized based on surficial deposits and landforms, subsurface information, and previous work on the interpretation of glacial deposits. Ice-marginal positions, which represent pauses in the retreat of glacial ice were inferred from this information. Long pauses in ice retreat favored the accumulation of coarse-grained deposits (and formation of unconfined aquifers), whereas more steady or rapid ice retreat favored deposition of fine-grained lacustrine deposits with limited confined aquifers composed of coarse-grained deposits at depth. Unconfined aquifers with thick saturated zones, primarily kame sand and gravel, are the most favorable aquifer settings, and three several-mile-long sections of valley were identified (mostly in Broome County) as potentially favorable in this regard: (1) the southernmost valley section, which extends from the New York-Pennsylvania border to about 1 mile north of South Windsor, (2) the valley section that rounds the west side of the umlaufberg (an isolated bedrock hill within a valley) north of Windsor, and (3) the east-west valley section at the Broome County-Chenango County border from Nineveh to East of Bettsburg (including the lower reach of the Cornell Brook Valley). Areas with substantial high-altitude outwash overlying lacustrine deposits are likely thinly saturated and are, therefore, limited aquifers. Fine-grained lacustrine deposits form extensive confining units between the unconfined areas, and the water-resource potential of underlying confined aquifers is largely untested. Favorable settings for confined aquifers include locations where the saturated thickness of sand and gravel is sufficient to accommodate a well screen and where these permeable deposits are in hydraulic connection with unconfined aquifers of kame sand and gravel-either associated with ice-margin positions or along valley walls.

Water-resource development in the region is mostly in the form of domestic wells; three villages provide community 
supplies. Most domestic wells in upland areas tap the fractured bedrock aquifer. Domestic wells in the Susquehanna River valley may tap sand and gravel deposits with open-ended well casings or may be completed as bedrock wells that are cased through the valley-fill deposits. Community supplies consist of screened production wells that tap sand and gravel deposits beneath or adjacent to alluvial fan deposits. Some of these wells may induce infiltration of Susquehanna River water. The maximum reported yield of production wells is about 350 gallons per minute.

Water-resource protection of the Susquehanna River valley-fill aquifer includes not only aquifer extent, but also upland areas that contribute water to the aquifer such as adjacent hillsides that drain directly to the Susquehanna River valley, and the drainage areas of tributary streams that lose water to the aquifer upon entering the valley. Of particular note are watersheds of streams that contribute water through alluvial fans where there are currently (2012) withdrawals for public supply. Lastly, protection of water resources in upland areas can include restriction of activities that may compromise groundwater quality in areas where till is thin over bedrock or where bedrock crops out at land surface.

\section{References Cited}

Braun, D.D., 2006a, Surficial geology of the Great Bend 7.5-minute quadrangle, Susquehanna County, Pennsylvania: Pennsylvania Geological Survey Open-File Report OFSM06-03.0, 18 p., 1 plate.

Braun, D.D., 2006b, Surficial geology of the Susquehanna 7.5-minute quadrangle, Susquehanna County, Pennsylvania: Pennsylvania Geological Survey Open-File Report OFSM06-04.0, 18 p., 1 plate.

Braun, D.D., 2006c, Deglaciation of the Appalachian Plateau, northeastern Pennsylvania - till shadows, till knobs forming "beaded valleys"- Revisiting systematic stagnation-zone retreat: Geomorphology, v. 75, p. 248-265.

Braun, D.D., 2002, Quaternary history of the TunkhannockGreat Bend region, in Inners, J.D., and Fleeger, G.M., eds., From Tunkhannock to Starucca-Bluestone, glacial lakes, and great bridges in the "Endless Mountains" of northeastern Pennsylvania: Guidebook for the 67th Annual Field Conference of Pennsylvania Geologists, p. 32-38.

Cadwell, D.H., 1972, Late Wisconsinan deglaciation of the Chenango River Valley and vicinity, New York: State University of New York at Binghamton, unpublished PhD. dissertation, $102 \mathrm{p}$.

Coates, D.R., 1981, Geomorphology of south-central New York, in Enos, P., ed., New York State Geological Association, 53rd Annual Meeting field-trip guidebook, p. 171-200.
Coates, D.R., 1966, Glaciated Appalachian Plateau—till shadows on hills: Science, v. 152, p. 1617-1619.

Crain, L.J., 1966, Ground-water resources of the Jamestown area, New York, with emphasis on the hydrology of the major stream valleys: New York State Water Resources Commission Bulletin 58, $167 \mathrm{p}$.

Fisher, D.W., Isachsen, Y.W., and Rickard, L.V., 1970, Geologic map of New York, Hudson-Mohawk sheet: New York State Museum and Science Service, Map and Chart Series no. $15,1: 250,000$.

Fleisher, P.J., 1986a, Dead-ice sinks and moats: environments of stagnant ice deposition: Geology, v. 14, p. 39-42.

Fleisher, P.J., 1986b, Glacial geology and late Wisconsinan stratigraphy, upper Susquehanna drainage basin, New York, in Cadwell, D.H., ed., The Wisconsinan stage of the First Geological District, eastern New York: New York State Museum Bulletin Number 455, p. 121-142.

Fleisher, P.J., 1993, Pleistocene sediment sources, debris transport mechanisms, and depositional environments - a Bering Glacier model applied to northeastern AppalachianPlateau deglaciation, central New York: Geomorphology, v. 6, p. 331-355.

Harrison, J. E., 1966, Proglacial drainage evolution and deglaciation of the Great Bend region, Pennsylvania and New York: unpublished Master's thesis, State University of New York at Binghamton, N.Y., 71 p.

Hollyday, E.F., 1969, An appraisal of the ground-water resources of the Susquehanna River Basin in New York State: U.S. Geological Survey Open-File Report 69-128, 97 p., 1 pl.

King, C.A.M., and Coates, D.R., 1973, Glacio-periglacial landforms within the Susquehanna-Great Bend area of New York and Pennsylvania: Quaternary Research, v. 3, p. 600-620.

Kirkland J.T., 1973, Glacial Geology of the western Catskills, PhD. dissertation, State University of New York at Binghamton, 105 p., 5 pls.

Koteff, Carl, and Pessl, Fred Jr., 1981, Systematic ice retreat in New England: U. S. Geological Survey Professional Paper $1179,20 \mathrm{p}$.

Lane, J.W., Jr., White, E.A., Steele, G.V., and Cannia, J.C., 2008, Estimation of bedrock depth using the horizontal-tovertical (H/V) ambient-noise seismic method, in Symposium on the Application of Geophysics to Engineering and Environmental Problems, April 6-10, 2008, Philadelphia, Pennsylvania, Proceedings: Denver, Colo., Environmental and Engineering Geophysical Society, 13 p. 
MacNish, R.D., and Randall, A.D., 1982, Stratified-drift aquifers in the Susquehanna River Basin, New York: New York State Department of Environmental Conservation Bulletin 75, $68 \mathrm{p}$.

McPherson, W.S., 1993, Hydrogeology of unconsolidated deposits in Chenango County, New York: U.S. Geological Survey Water-Resources Investigations Report 91-4138, 43 p., 3 pls (on 6 sheets).

Morrissey, D.J., Randall, A.D., and Williams, J.H., 1988, Upland runoff as a major source of recharge to stratified drift in the glaciated northeast, in, Randall, A.D. and Johnson, A.I., eds., Regional Aquifer systems of the United States-The northeast glacial aquifers: American Water Resources Association Monograph Series no. 11, p. 17-36.

Ozvath, D.L., 1985, Glacial geomorphology and late Wisconsinan deglaciation of the western Catskill Mountains, New York: State University of New York at Binghamton, Ph.D. dissertation, $181 \mathrm{p}$.

Randall, A.D., 2001, Hydrogeologic framework of stratifieddrift aquifers in the glaciated northeastern United States: U.S. Geological Survey Professional Paper 1415-B, 179 p., $1 \mathrm{pl}$.

Randall, A.D., 1978, Infiltration from tributary streams in the Susquehanna River Basin: U.S. Geological Survey Journal of Research, v. 6, no. 3, p. 285-297.

Randall, A.D., 1972, Records of wells and test borings in the Susquehanna River Basin, New York: New York State Department of Environmental Conservation Bulletin 69, $92 \mathrm{p}$.

Rickard, L.V., and Fisher, D.W., 1970, Geologic map of New York, Finger Lakes sheet: New York State Museum and Science Service, Map and Chart Series no. 15, 1:250,000.

Scully, R.W., and Arnold, R.W., 1981, Holocene alluvial stratigraphy in the upper Susquehanna River Basin, New York: Quaternary Research, v. 15, p. 327-344.

Thieme, D.M., 2002, The Great Bend and Halstead Park archaeological sites, in Inners, J.D., and Fleeger, G.M., eds., From Tunkhannock to Starucca-Bluestone, glacial lakes, and great bridges in the "Endless Mountains" of northeastern Pennsylvania: Guidebook for the 67th Annual Field Conference of Pennsylvania Geologists, p. 44-48.

United States Department of Agriculture, 2008, Soil Survey Geographic (SSURGO) Database for Broome and Chenanago Counties, New York, accessed October 30, 2008, at http://soildatamart.nrcs.usda.gov.

United States Environmental Protection Agency, n.d., EPA Safe Drinking Water Information System (SDWIS) database, accessed July 14, 2010, at http://oaspub.epa.gov/ enviro/sdw_form_v2.create_page?state_abbr=NY.
U.S. Geological Survey, 2001, National Water Information System (NWISWeb): U.S. Geological Survey database, accessed October 5, 2012, at http://waterdata.usgs.gov/nwis/

Wedel, A.A., 1932, Geologic structure of the Devonian strata of south-central New York: New York State Museum Bulletin No. 294, 74 p., 1 pl.

Williams, J.H., 1991, Tributary-stream infiltration in Marsh Creek Valley, north-central Pennsylvania: U.S. Geological Survey Water-Resources Investigations Report 90-4052, $39 \mathrm{p}$.

Williams, J.H., and Eckhardt, D. A., 1987, Groundwater resources of the Berwick-Bloomsburg-Danville area, eastcentral Pennsylvannia: Pennsylvannia Geological Survey Water Resource Report 61; Harrisburg, Pennsylvannia, 76 p. 
THIS PAGE INTENTIONALLY LEFT BLANK 


\section{Appendix 1. Well data for Susquehanna River valley and adjacent uplands, eastern Broome and southeastern Chenango Counties, New York.}

http://pubs.usgs.gov/sir/2012/5282/appendix1/Appendix1.xlsx 
THIS PAGE INTENTIONALLY LEFT BLANK 
Prepared by the Pembroke and Rolla Publishing Service Center.

For more information concerning this report, contact:

\section{Director \\ U.S. Geological Survey}

New York Water Science Center

425 Jordan Road

Troy, NY 12180-8349

dc_ny@usgs.gov

or visit our Web site at:

http://ny.water.usgs.gov 
